\title{
DIFICULDADES DE APRENDIZAGEM E SEUS DESAFIOS
}

\section{ARTIGO ORIGINAL}

LAUSCHNER, Lorenice Schwertz Franz ${ }^{1}$

\section{LAUSCHNER, Lorenice Schwertz Franz. Dificuldades de aprendizagem e seus} desafios. Revista Científica Multidisciplinar Núcleo do Conhecimento. Ano. 06, Ed. 09, Vol. 06, pp. 60-97. Setembro 2021. ISSN: 2448-0959, Link de acesso: https://www.nucleodoconhecimento.com.br/pedagogia/aprendizagem, DOI: 10.32749/nucleodoconhecimento.com.br/pedagogia/aprendizagem

\section{RESUMO}

O presente artigo, busca averiguar quais são as dificuldades de aprendizagem e seus desafios para o professor nos Anos Iniciais do Ensino Fundamental, na Escola Municipal de Educação Básica José Theobaldo Utzig e Escola Municipal Ensino Fundamental Maria Terezinha, do município de Pinhalzinho-SC. Para isto, foi realizada uma pesquisa qualitativa, por meio de entrevista semiestruturada com os professores do primeiro ao quinto ano das escolas investigadas. Após entrevistas, foi constatado que as maiores dificuldades de aprendizagem são referentes a leitura e escrita, falta de atenção das crianças, e dificuldades em matemática. Os maiores desafios relatados pelos professores são: a falta de informação sobre as dificuldades de aprendizagem e falta de apoio pedagógico e orientação para realização de encaminhamentos à profissionais especializados. Ao final, concluímos que é necessário ao professor, receber apoio pedagógico e orientação para compreender as causas, consequências e as formas mais adequadas para minimizar as dificuldades de aprendizagem, de forma que este esteja sempre atualizado e informado sobre o assunto. Portanto, o professor tem o desafio de repensar as práticas pedagógicas, ter uma atenção especial quanto às habilidades de noção lógica matemática, linguagem oral e escrita, explorar a psicomotricidade desde a

\footnotetext{
${ }^{1}$ Mestrado em Educação. Especialização em Pedagogia em Educação Infantil e Psicopedagogia Institucional. Graduação em Pedagogia Educação Infantil.
} 
primeira infância com a criança, pensando sempre em um caráter preventivo as futuras dificuldades de aprendizagem. E assim, favorecer a inclusão, acolhimento e construção de conhecimento, fazendo com que a escola seja um espaço de novas possibilidades, oportunidades para a vida.

Palavras-Chave: Dificuldades de Aprendizagem, Desafio, Ensino Fundamental.

\section{INTRODUÇÃO}

As dificuldades de aprendizagem sempre foram um desafio para os professores em todos os níveis de ensino, causando muitas dúvidas e insegurança, especialmente no Ensino Fundamental. Segundo Pires (2010), no século XVIII e XIX, os educadores já se sentiam despreparados para agir diante das dificuldades.

Pires (2010), explica que as dificuldades de aprendizagem já despertavam a atenção dos estudiosos nesta época, sendo questionado o que seria "normal" e "anormal" nas crianças na escola, causando rotulação de alunos, considerando-os incapaz de aprender. Entendia-se que os problemas relacionados à aprendizagem seriam uma Síndrome da Disfunção Cerebral Mínima, uma pequena dificuldade na leitura, em cálculos, dificuldades na concentração, dificuldade nas habilidades necessárias para um bom desempenho escolar.

Segundo Perrenoud (2004) a reprovação para casos desta natureza não é a solução mais adequada. A reprovação afeta a autoimagem da criança, o seu valor aos olhos dos outros, o seu atraso escolar (defasagem entre real e idade e "normal"), se tornando uma deficiência no momento de qualquer decisão posterior. Conforme Perrenoud (2004, p. 37): "A reprovação é inútil e injusta, não tem resposta eficaz e equinâmine às dificuldades de aprendizagem... Devem ser buscadas outras respostas à heterogeneidade." Golstein et al (2006), relata que o professor precisa ter muito conhecimento e competência profissional para saber minimizar a dificuldade de aprendizagem de uma criança. 
No entanto, a pesquisa busca investigar quais são as dificuldades de aprendizagem encontradas nas Séries Iniciais do Ensino Fundamental e os desafios do professor perante elas, nas escolas municipais de Pinhalzinho, Santa Catarina. As escolas escolhidas para o estudo, foram: Escola Municipal de Ensino Básico José Theobaldo Utzig e Escola Municipal de Ensino Fundamental Maria Terezinha. A pesquisa realizada ocorreu no ano de 2011.

Para as crianças com dificuldades de aprendizagem, é aconselhável ter uma atenção especial, fazer um encaminhamento para um profissional da saúde se necessário e realizar um trabalho pedagógico que ajude a superar as dificuldades de aprendizagem na escola. O estudo mostra novas possibilidades para que 0 educador melhore a sua prática, com sugestões, ajudando a encontrar maneiras de superar as dificuldades de seus alunos, melhorando a qualidade de ensino, elencando uma prática pedagógica de carácter preventivo.

\section{DIFICULDADES DE APRENDIZAGEM}

A dificuldade de aprendizagem é considerada como uma perturbação do processo psicológico básico, que envolve a compreensão, linguagem escrita ou oral, interferindo no processo de leitura e escrita, cálculos. As causas podem ser de ordem perceptiva, de lesão cerebral, disfunção cerebral mínima, dislexia, afasia de desenvolvimento, conforme Carvalho (2007). Crianças com dificuldade de aprendizagem geralmente apresentam problemas de déficit em habilidades sociais desenvolvendo sentimentos de baixo autoestima e inferioridade na adolescência, causando desadaptação social associada a evasão escolar. Além disso, gera um círculo vicioso do fracasso escolar, fazendo a criança se sentir cada vez mais inferiorizada e suscetível ao insucesso, diminuindo sempre mais as chances de ser aprovado a partir de seu desempenho escolar. Podem manifestar-se dificuldades de percepção tátil, visual, habilidades de coordenação motora, destreza, e insegurança diante do novo, de acordo Carvalho (2007).

Para Collares (1989), o fracasso escolar é um dos mais graves problemas que a educação brasileira possui, principalmente nos primeiros anos de ensino, há várias 
décadas. Existem vários fatores relacionados, como as condições de vida e subsistência, as péssimas condições econômicas, a fome, a desnutrição; a falta de moradias adequadas e de saneamento básico, que algumas crianças têm. As crianças de classe social desfavorecidas, são privados de muitas coisas e por isso, podem ter um desempenho escolar menos desenvolvido, manifestando desta forma, as dificuldades de aprendizagem ao frequentar a escola.

Quando as dificuldades de aprendizagem se manifestam, o professor tem o desafio de observar a criança, auxiliar na aprendizagem dela, desenvolver aulas diversificadas para que ela se desenvolva de forma integral, utilizando diferentes estratégias. As habilidades necessárias no processo de alfabetização e de Matemática, deverão ser desenvolvidas no ambiente escolar através de experiências e atividades lúdicas como: contação de histórias, uso de rimas, jogo com palavras que auxiliam no processo de leitura e escrita, quadrinhas, músicas, cantigas etc. Noções lógicas podem ser exploradas com as crianças desde pequenas, quantificando materiais concretos, jogos matemáticos como dominó, jogos de memória, usando cantigas e músicas diversas que ajudam na noção de tempo, espaço, número, quantidade, soma, subtração, divisão, entre outros conceitos importantes, segundo Sanches et al (2011).

O brincar é uma experiência extremamente necessária para a infância. É um momento em que a criança se manifesta através de sua essência, mostrando sua realidade, construindo novos conhecimentos e ao mesmo tempo desenvolvendo as suas habilidades emocionais, cognitivas, físicas e psicológicas, de acordo com Sanches et al (2011).

Segundo Freitas e Corso (2016), é possível prevenir algumas dificuldades de aprendizagem relacionadas à leitura, escrita e matemática, diretamente influenciadas pela psicomotricidade, através de brincadeiras tradicionais. A educação psicomotora é importante no desenvolvimento da criança desde o seu nascimento, está diretamente ligado com o processo de alfabetização e conhecimento matemático, oportunizando que a criança se desenvolva melhor em seu ambiente, prevenindo as dispraxias e disgnosias. As dispraxias são alterações 
no desenvolvimento do gesto em relação ao seu próprio corpo ou objeto relacionados à uma intenção, como: dificuldades para usar tesoura, lápis, dificuldades de coordenação de movimentos etc. $E$ disgnosias são atrasos e alterações das percepções, podendo ser auditivas, tátil, olfativa, de noção espacial, temporal e outras.

É na infância que a criança pode aprender e desenvolver suas habilidades de forma integral através do brincar, participar, conviver, expressar, explorar, conhecer-se. Nas etapas seguintes do ensino, a criança aperfeiçoa ainda mais as suas inteligências múltiplas, desenvolve as demais habilidades e competências necessárias para a sua vida, e para isso, o sucesso deste processo depende da base inicial, construída na primeira infância, conforme Brasil (2018).

\section{MÉTODO}

A pesquisa foi realizada no ano de 2011 em duas escolas municipais mantidas pelo poder público municipal de Pinhalzinho. Ambas possuem estrutura boa, os professores são todos graduados, especialistas, alguns são efetivos e outros admitidos por caráter temporário. As duas escolas atualmente possuem diretor, orientadores pedagógicos que acompanham o processo de ensino e aprendizagem. A EMEB José Theobaldo Utzig está situada próximo ao centro da cidade, no Bairro EFACIP, atende as crianças da cidade, bairros próximos e interior, contendo, aproximadamente, 700 alunos. A EMEF Maria Terezinha, foi atualmente reestruturada tem funcionado em outro endereço com outra nomenclatura, passando a ser conhecida como "EMEB Don José Gomes". Esta, atende as crianças do Bairro Jardim Maria Terezinha, um bairro mais carente da cidade, e de alguns bairros próximos, possuindo cerca de 400 alunos, do primeiro ao oitavo ano.

A pesquisa foi realizada através de algumas perguntas para 15 professores que na época compunham o quadro de funcionários das escolas pesquisadas. As questões foram elaboradas pelos autores, tendo um enfoque subjetivista, compreensivista, crítico, com visão histórica e estrutural, procurando desvendar a realidade da educação do município de Pinhalzinho. Foram elaboradas 8 questões, sendo elas: 
- Qual a idade do professor, tempo de serviço, sua formação, e tipo de contratação?

- Em qual turma atua no momento?

- Por que escolheu ser professor?

- Quais os maiores desafios de um professor?

- Existem dificuldades de aprendizagem na sua turma? Quais?

- O que o professor faz diante das dificuldades de aprendizagem?

- No final do ano letivo, quando a dificuldade de aprendizagem persiste, que atitudes o professor tem no momento da avaliação?

- O professor recebe apoio de orientação escolar, pedagógico quando tem dificuldades de aprendizagem na turma?

Foi realizado, também, um estudo teórico de levantamento bibliográfico. As interpretações e explicações da coleta de dados são ideias supostas, análise de alguns autores que explicam as dificuldades de aprendizagem, os distúrbios e transtornos de aprendizagem, as causas e consequências no processo de ensino e aprendizagem.

É importante ressaltar que as dificuldades de aprendizagem são interpretadas conforme o momento histórico que a educação do município perpassa e conforme a realidade de cada docente. $O$ estudo foi desenvolvido com coleta de dados a partir de entrevista gravada, "verbi gratia", a qual foi analisada, interpretada e transcrita. A técnica usada foi uma entrevista estruturada. Foi realizado um levantamento de dados, para conhecer a realidade das escolas e dos professores, compreender quais são as dificuldades de aprendizagem e seus desafios para o professor.

A interpretação de dados da entrevista foi baseada nas técnicas de Laurence Bardin (2010) e Augusto Trivinos (2009), usando a Técnica da Análise Temática, Análise das Atitudes Valorizadas e Rejeitadas e Análise do Estereótipo dos professores entrevistados averiguando os resultados em funções variáveis externas e relativas. 


\section{RESULTADOS DA PESQUISA}

O grupo de professores nas escolas municipais, no Ensino Fundamental nos Anos Iniciais, conforme o constatado na pesquisa, é experiente, alguns professores são mais jovens, outros com idade superior a 30 anos de idade. Possuem formação na área, graduados e especializados, o que deveria gerar mais eficiência no processo de ensino e aprendizagem, como mostra a Tabela 1. As interpretações das respostas dadas foram baseadas na Análise de Conteúdo de Laurence Bardin (2010), na observação das características dos educadores como: a idade, sexo, o tempo de serviço e o tipo de contratação, o que de uma forma ou outra interfere no desempenho profissional.

Tabela 1- Análise dos resultados em função de variáveis externas relativas

\begin{tabular}{|c|c|c|c|c|c|c|c|}
\hline Sequência: & $\begin{array}{l}\text { Idade dos } \\
\text { Professores: }\end{array}$ & $\begin{array}{l}\text { Tempo } \\
\text { de } \\
\text { Serviço: }\end{array}$ & Formação: & & & $\begin{array}{l}\text { Tipo de } \\
\text { Contrato: }\end{array}$ & $\begin{array}{l}\text { Série } \\
\text { em } \\
\text { que } \\
\text { atua: }\end{array}$ \\
\hline 1 & 36 anos & 14 anos & $\begin{array}{l}\text { Pedagogia } \\
\text { Graduação } \\
\text { Pedagogia }\end{array}$ & e & $\begin{array}{l}\text { Pós- } \\
\text { em }\end{array}$ & ACT 40h & $\begin{array}{l}2^{\circ} \\
\text { ano }\end{array}$ \\
\hline 2 & 44 anos & 14 anos & $\begin{array}{l}\text { Pedagogia } \\
\text { Graduação } \\
\text { Pedagogia }\end{array}$ & e & $\begin{array}{l}\text { Pós- } \\
\text { em }\end{array}$ & $\begin{array}{l}\text { ACT } 20 \mathrm{~h} \mathrm{e} \\
\text { efetiva } \\
20 \mathrm{~h}\end{array}$ & $\begin{array}{l}1^{\circ} \\
\text { ano }\end{array}$ \\
\hline 3 & 50 anos & 24 anos & $\begin{array}{l}\text { Pedagogia } \\
\text { Graduação } \\
\text { Pedagogia }\end{array}$ & e & $\begin{array}{l}\text { Pós- } \\
\text { em }\end{array}$ & $\begin{array}{l}\text { ACT } 20 \mathrm{~h} \\
\mathrm{e} \text { efetiva } \\
20 \mathrm{~h}\end{array}$ & $\begin{array}{l}4^{\circ} \\
\text { ano }\end{array}$ \\
\hline 4 & 23 anos & 2 anos & $\begin{array}{l}\text { Pedagogia } \\
\text { Graduação }\end{array}$ & e & Pós- & ACT 40h & $\begin{array}{l}1^{\circ} \\
\text { ano }\end{array}$ \\
\hline 5 & 41 anos & 15 anos & Pedagogia & $e$ & Pós- & Efetiva & $4^{\underline{a}}$ \\
\hline
\end{tabular}




\begin{tabular}{|c|c|c|c|c|c|}
\hline & & & $\begin{array}{lr}\text { Graduação } & \text { em } \\
\text { Pedagogia } & \text { e } \\
\text { Psicopedagogia } & \\
\text { Clínica } & \text { e } \\
\text { Institucional } & \end{array}$ & $40 h$ & série \\
\hline 6 & 39 anos & 14 anos & $\begin{array}{llr}\text { Pedagogia e } & \text { Pós- } \\
\text { Graduação } & \text { em } \\
\text { Pedagogia } & \end{array}$ & $\begin{array}{l}\text { ACT 20h e } \\
20 \mathrm{~h} \\
\text { efetiva }\end{array}$ & $\begin{array}{l}4^{a} \\
\text { série }\end{array}$ \\
\hline 7 & 46 anos & 25 anos & $\begin{array}{l}\text { Pedagogia e Pós- } \\
\text { Graduação }\end{array}$ & $\begin{array}{l}40 \mathrm{~h} \\
\text { efetiva }\end{array}$ & $\begin{array}{l}1^{\circ} \\
\text { ano }\end{array}$ \\
\hline 8 & 39 anos & 20 anos & $\begin{array}{l}\text { Pedagogia e Pós- } \\
\text { Graduação em } \\
\text { Psicopedagogia } \\
\text { Institucional, Gestão } \\
\text { Escolar, e Educação } \\
\text { a Distância }\end{array}$ & $\begin{array}{l}40 \quad h \\
\text { efetiva }\end{array}$ & $\begin{array}{l}3^{\circ} \\
\text { ano }\end{array}$ \\
\hline 9 & 44 anos & 25 anos & $\begin{array}{llr}\text { Pedagogia e } & \text { Pós- } \\
\text { Graduação } & \text { em } \\
\text { Pedagogia } & \end{array}$ & $\begin{array}{l}\text { Efetiva } 40 \\
\mathrm{~h}\end{array}$ & $\begin{array}{l}2^{\circ} \\
\text { ano }\end{array}$ \\
\hline 10 & 47 anos & 26 anos & $\begin{array}{llr}\text { Pedagogia e } & \text { Pós- } \\
\text { Graduação } & \text { em } \\
\text { Pedagogia } & \end{array}$ & $\begin{array}{l}\text { Efetiva } 40 \\
\mathrm{~h}\end{array}$ & $\begin{array}{l}3^{\circ} \\
\text { ano }\end{array}$ \\
\hline 11 & 46 anos & 27 anos & $\begin{array}{llr}\text { Pedagogia e } & \text { Pós- } \\
\text { Graduação } & \text { em } \\
\text { Pedagogia } & \end{array}$ & $\begin{array}{l}\text { Efetivo } \\
40 \mathrm{~h}\end{array}$ & $\begin{array}{l}4^{\mathrm{a}} \\
\text { série }\end{array}$ \\
\hline 12 & 27 anos & 1 ano & $\begin{array}{l}\text { Pedagogia e Pós- } \\
\text { Graduação }\end{array}$ & ACT 20h & $\begin{array}{l}4^{\circ} \\
\text { ano }\end{array}$ \\
\hline 13 & 37 anos & 6 anos & 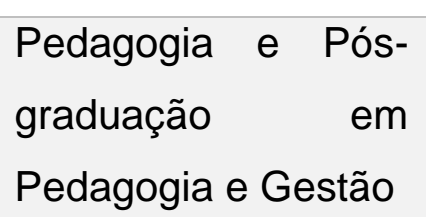 & ACT $20 \mathrm{~h}$ & $\begin{array}{l}4^{a} \\
\text { série }\end{array}$ \\
\hline 14 & 31 anos & 12 anos & Pedagogia e Pós- & Efetiva & $2^{\circ}$ \\
\hline
\end{tabular}

$\mathrm{RC}: 97780$

Disponível em: https://www.nucleodoconhecimento.com.br/pedagogia/aprendizagem 


\begin{tabular}{|c|c|c|c|c|c|}
\hline & & & graduação & $60 \mathrm{~h}$ & ano \\
\hline 15 & 37 anos & 16 anos & $\begin{array}{l}\text { Pedagogia e Pós- } \\
\text { graduação } \\
\text { Psicopedagogia }\end{array}$ & ACT 40h & $\begin{array}{l}3^{0} \\
\text { ano }\end{array}$ \\
\hline
\end{tabular}

Fonte: $A$ autora.

Referente a idade, tempo de serviço e tipo de contratação, conforme relatos dos professores, entre as quinze pessoas entrevistadas, três são mais jovens, com idade entre vinte e três e trinta e um anos. Cinco professoras têm entre trinta e seis a trinta e nove anos. Seis educadoras têm de quarenta e três a quarenta sete anos e outra educadora cinquenta anos. Percebe-se que apenas três professoras têm menos experiência, até seis anos, seis pessoas têm entre doze e dezesseis anos de tempo de serviço e outras seis educadoras têm entre vinte e vinte e sete anos de profissão docente. Oito professoras são Admitidas por Caráter Temporário e sete estão efetivas por quarenta horas. Três professores são efetivos vinte horas semanais, em estágio probatório e mais vinte horas por Admissão de Caráter Temporário. Isso explica a angústia de alguns professores, por ter uma carreira instável, com remuneração menor, tendo algumas desvantagens no Plano de Carreira, onde apenas os efetivos recebem: Licença Prêmio (licença para se afastar três meses do trabalho com remuneração, a cada cinco anos trabalhados), Adicional por Tempo de Serviço a cada três anos trabalhados, (com 3\% a mais na remuneração) e Progressão ao Mérito, (direito a um percentual a mais a cada ano), com apresentação de certificado de quarenta horas de Curso de Aperfeiçoamento com avaliação do desempenho profissional, de acordo com o Plano de Carreira Municipal e Estatuto do Servidor Municipal.

Estas são alguns aspectos que confirmam o quão difícil é ser professor, levando em conta também a política nacional de valorização do magistério no Brasil. Considerando as dificuldades indicadas, o presente artigo mostra os desafios que os educadores encontram no processo de ensino e aprendizagem. 
A tabela a seguir mostra os relatos de forma íntegra dos professores entrevistados, ao perguntar: Quais são os maiores desafios de um professor?

Tabela 2 - Análise temática: quais os maiores desafios de um professor?

\begin{tabular}{|c|c|c|c|}
\hline Temática: & $\begin{array}{l}\text { Resposta do } \\
\text { Professor: }\end{array}$ & Sequência: & Enunciado: \\
\hline 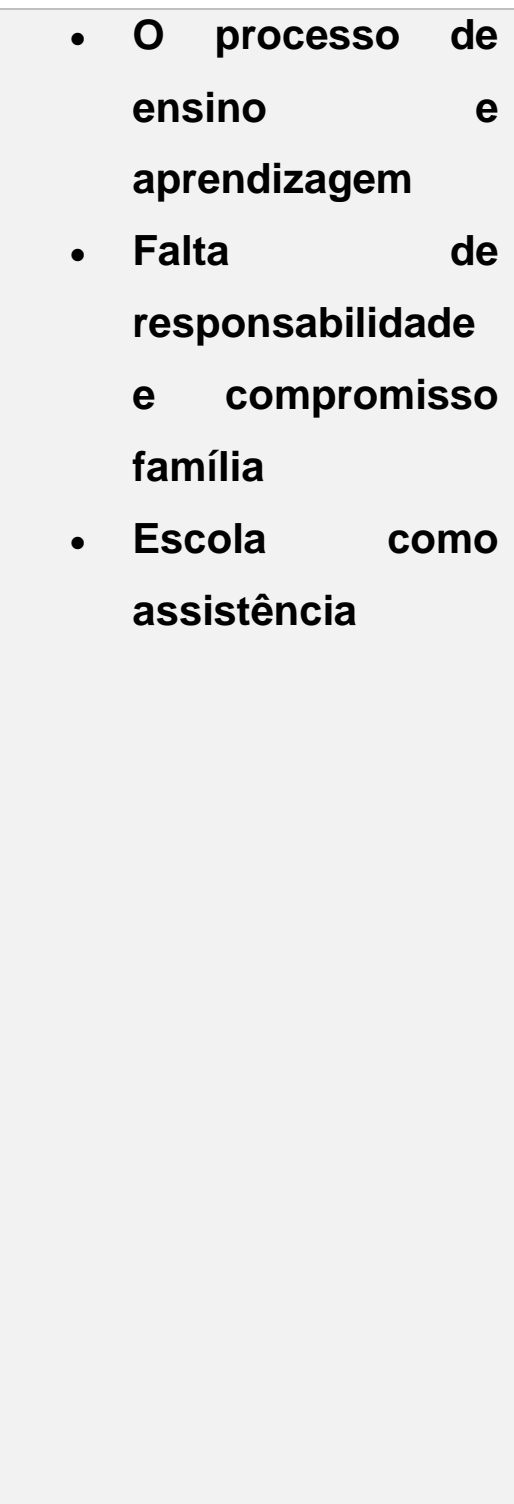 & 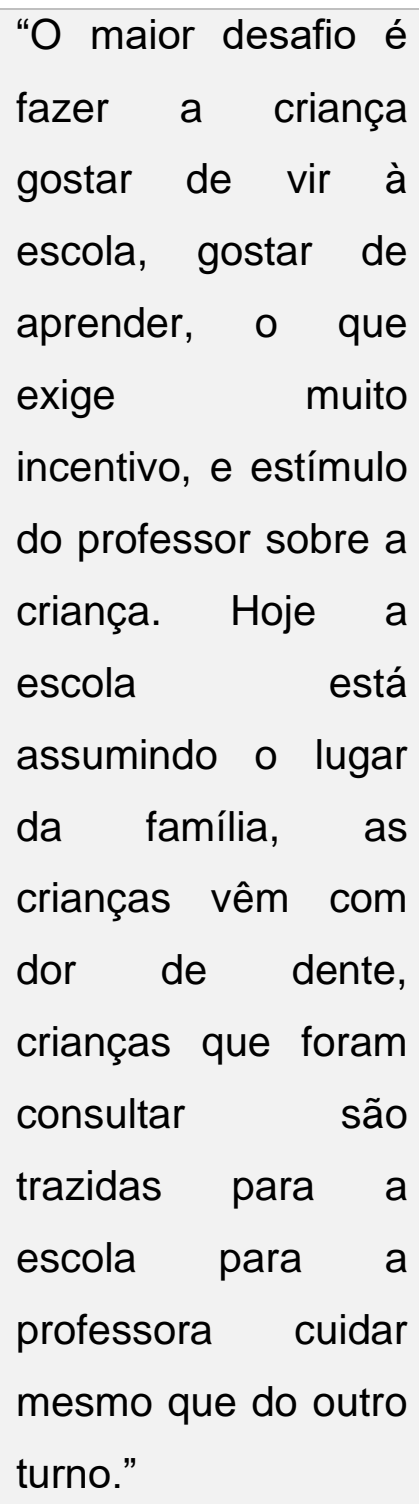 & 1 & $\begin{array}{l}\text { Falou com } \\
\text { firmeza } \\
\text { segurança, } \\
\text { desabafando } \\
\text { suas angústias. }\end{array}$ \\
\hline $\begin{array}{l}\text { Excesso de } \\
\text { alunos por sala } \\
\text { - Dificuldades de }\end{array}$ & $\begin{array}{l}\text { "O maior desafio é } \\
\text { quando tem muitos } \\
\text { alunos numa sala e } \\
\text { alguns não }\end{array}$ & 2 & $\begin{array}{lr}\text { Falou } & \text { com } \\
\text { firmeza, } & \text { se } \\
\text { mostrou muito } & \\
\text { preocupado. } & \end{array}$ \\
\hline
\end{tabular}




\begin{tabular}{|c|c|c|c|c|}
\hline & aprendizagem & $\begin{array}{l}\text { compreendem a } \\
\text { leitura, não } \\
\text { aprendem a ler e } \\
\text { escrever". }\end{array}$ & & \\
\hline$\bullet$ & $\begin{array}{l}\text { Ausência da } \\
\text { responsabilidade } \\
\text { da família } \\
\text { Professores } \\
\text { sobrecarregados } \\
\text { com conteúdo e } \\
\text { projetos. } \\
\text { Ausência de } \\
\text { profissionais } \\
\text { especializados } \\
\text { para atender as } \\
\text { dificuldades de } \\
\text { aprendizagem }\end{array}$ & 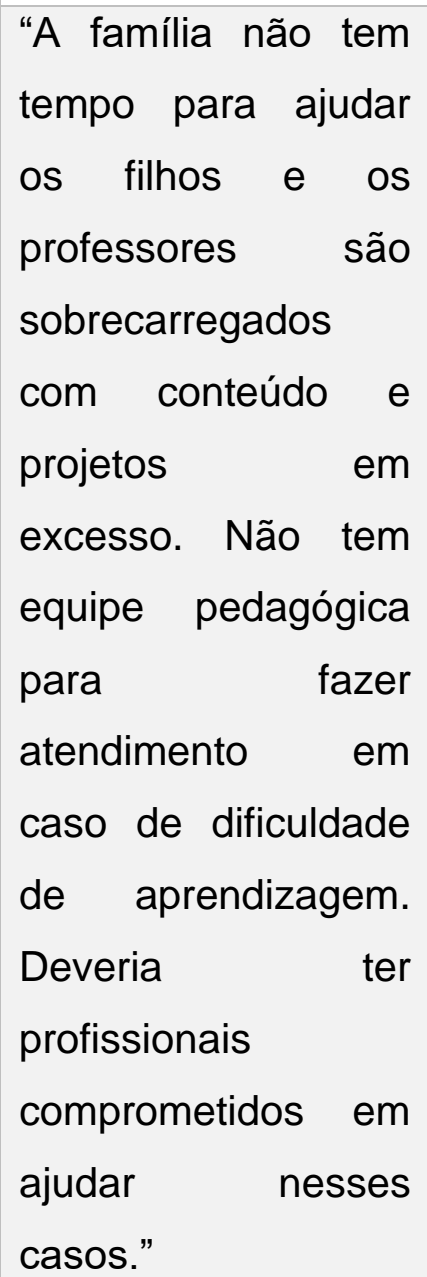 & 3 & $\begin{array}{l}\text { Se mostrou } \\
\text { preocupado } \\
\text { angustiado, por } \\
\text { não ter muita } \\
\text { informação e não } \\
\text { receber ajuda. }\end{array}$ \\
\hline & $\begin{array}{l}\text { Dificuldade de } \\
\text { aprendizagem }\end{array}$ & $\begin{array}{l}\text { "São as dificuldades } \\
\text { de aprendizagem } \\
\text { dos alunos, esses } \\
\text { alunos com dislexia, } \\
\text { discalculia, a falta de } \\
\text { vontade desses } \\
\text { alunos." }\end{array}$ & 4 & $\begin{array}{l}\text { Falou com } \\
\text { entusiasmo, } \\
\text { preocupação e } \\
\text { insegurança } \\
\text { quanto a suas } \\
\text { atitudes como } \\
\text { educador. }\end{array}$ \\
\hline & $\begin{array}{l}\text { Dificuldade de } \\
\text { aprendizagem }\end{array}$ & $\begin{array}{l}\text { "As dificuldades de } \\
\text { aprendizagem, a }\end{array}$ & 5 & $\begin{array}{l}\text { O professor se } \\
\text { mostrou tenso, }\end{array}$ \\
\hline
\end{tabular}


- Falta de material falta de material nas nas escolas

- Alunos desinteressados

- Excesso de os alunos não dão alunos por sala.

- Desvalorização profissional

- O processo ensino aprendizagem

- Professor sobrecarregado, com conteúdo e muita cobrança

- Ausência dos pais na escola

- Pouco apoio da direção diante dos problemas escolas, a falta de significação ao aprendizado escolar, importância ao estudo! O número elevado de alunos por sala também é um desafio, não se consegue atender os alunos com dificuldades de aprendizagem de forma individual".

"Há uma falta de 6
respeito muito grande em relação e ao professor na sala de aula e a aprendizagem do aluno para 0 professor é um desafio! Só me sinto bem quando a aprendizagem

acontece, caso contrário, me sinto muito culpada. Existe muita cobrança, é muito preocupado.

Desânimo. Frases que mostram sinceridade, honestidade, preocupação.

Professor cansado, sobrecarregado 


\begin{tabular}{|c|c|c|c|}
\hline & $\begin{array}{l}\text { conteúdo para } \\
\text { ensinar. Os pais não } \\
\text { participam mais, } \\
\text { vêm pouco para a } \\
\text { escola, anos atrás } \\
\text { eles vinham mais e o } \\
\text { pior que sempre } \\
\text { defendem seu filho } \\
\text { quando há um } \\
\text { problema. Nestes } \\
\text { casos a direção } \\
\text { ajuda pouco, acaba } \\
\text { sobrando para o } \\
\text { professor." }\end{array}$ & & \\
\hline $\begin{array}{l}\text { - Falta de limites } \\
\text { dos alunos, } \\
\text { - Ausência da } \\
\text { família na escola }\end{array}$ & $\begin{array}{l}\text { "A questão dos } \\
\text { limites dos alunos, a } \\
\text { família não cumpre } \\
\text { com as } \\
\text { responsabilidades } \\
\text { com os filhos, a } \\
\text { família ausente, e a } \\
\text { questão } \\
\text { comportamento } \\
\text { quando a família não } \\
\text { acompanha seu filho } \\
\text { na escola. }\end{array}$ & 7 & $\begin{array}{l}\text { Se mostrou } \\
\text { angustiado, } \\
\text { frustrado, sem } \\
\text { apoio da família. }\end{array}$ \\
\hline 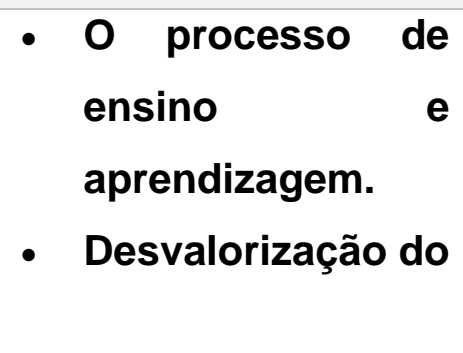 & $\begin{array}{l}\text { Conseguir fazer o } \\
\text { aluno aprender a } \\
\text { partir de várias } \\
\text { metodologias } \text { e } \\
\text { compreender o que }\end{array}$ & 8 & $\begin{array}{l}\text { Se mostrou bem } \\
\text { seguro ao falar, é } \\
\text { preocupado com } \\
\text { seus alunos. }\end{array}$ \\
\hline
\end{tabular}




\begin{tabular}{|c|c|c|c|}
\hline educador. & $\begin{array}{l}\text { foi ensinado. É } \\
\text { preciso aceitar o } \\
\text { aluno com sua } \\
\text { bagagem de } \\
\text { conhecimento da } \\
\text { mídia, por } \\
\text { computador é } \\
\text { exemplo, isso é um } \\
\text { desafio, pois } \\
\text { preciso aceitar e } \\
\text { saber aproveitar } \\
\text { esse conhecimento } \\
\text { extra na aula. Os } \\
\text { alunos sabem mais } \\
\text { em certas situações! } \\
\text { " }\end{array}$ & & \\
\hline 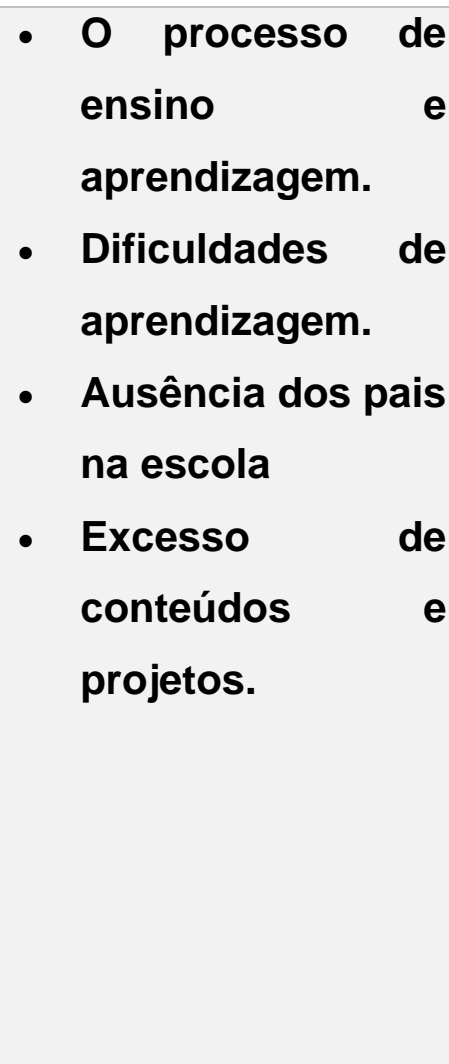 & 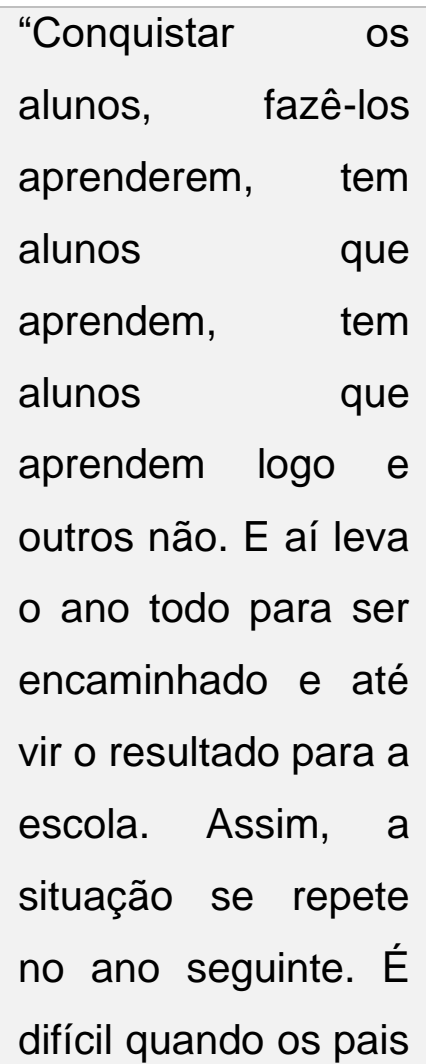 & 9 & $\begin{array}{l}\text { Professor } \\
\text { angustiado, } \\
\text { preocupado, } \\
\text { frustrado com a } \\
\text { prática educativa, } \\
\text { e estressado. Se } \\
\text { mostrou com } \\
\text { medo de falar, de } \\
\text { revelar algo, } \\
\text { medo de ser } \\
\text { comprometido. } \\
\text { Tinha muito } \\
\text { cuidado para } \\
\text { falar. }\end{array}$ \\
\hline
\end{tabular}




\begin{tabular}{|c|c|c|c|}
\hline & $\begin{array}{l}\text { não colaboram } \\
\text { muito, quando os } \\
\text { pais ajudam, o } \\
\text { resultado é maio! É } \\
\text { também um desafio } \\
\text { a quantidade de } \\
\text { conteúdos de } \\
\text { projetos, re } \\
\text { precisam } \\
\text { trabalhados. } \\
\text { professor não dá } \\
\text { conta de todo o } \\
\text { conteúdo." }\end{array}$ & & \\
\hline $\begin{array}{l}\text { - O processo de } \\
\text { ensino e } \\
\text { aprendizagem, } \\
\text { - A falta de limites } \\
\text { dos alunos }\end{array}$ & $\begin{array}{l}\text { "A aprendizagem da } \\
\text { criança e } \\
\text { relacionamento com } \\
\text { ela. A questão do } \\
\text { respeito, precisamos } \\
\text { negociar o tempo } \\
\text { todo. Hoje os alunos } \\
\text { têm mais direitos e } \\
\text { deveres, e até com } \\
\text { os pais fazem mais } \\
\text { do que deveriam". }\end{array}$ & 10 & $\begin{array}{l}\text { Preocupado e } \\
\text { angustiado. }\end{array}$ \\
\hline $\begin{array}{l}\text { - Falta de limites } \\
\text { dos alunos. } \\
\text { - A inclusão de } \\
\text { alunos. } \\
\text { - Excepcionais na } \\
\text { escola. } \\
\text { - Excesso de }\end{array}$ & $\begin{array}{l}\text { "A questão dos } \\
\text { limites dos alunos, a } \\
\text { falta de respeito e a } \\
\text { inclusão de alunos } \\
\text { excepcionais. A } \\
\text { inclusão é muito } \\
\text { bonita nos livros, na }\end{array}$ & 11 & $\begin{array}{l}\text { Falou com } \\
\text { firmeza, } \\
\text { segurança } \\
\text { coragem, } \\
\text { desabafando } \\
\text { sobre seus } \\
\text { problemas. }\end{array}$ \\
\hline
\end{tabular}




\begin{tabular}{|c|c|c|c|}
\hline alunos por sala. & $\begin{array}{l}\text { televisão, mas na } \\
\text { prática a realidade é } \\
\text { outra, porque é } \\
\text { preciso trabalhar } \\
\text { com muitos alunos } \\
\text { numa sala." }\end{array}$ & & \\
\hline $\begin{array}{l}\text { - Falta de limites } \\
\text { dos alunos. }\end{array}$ & $\begin{array}{l}\text { "O comportamento, } \\
\text { a atitude dos alunos. } \\
\text { A vida lá fora, a } \\
\text { rebeldia, a falta de } \\
\text { respeito é um fato } \\
\text { geral que precisa ser } \\
\text { muito trabalhado." }\end{array}$ & 12 & $\begin{array}{l}\text { Se mostrou } \\
\text { angustiada, } \\
\text { frustrada }\end{array}$ \\
\hline 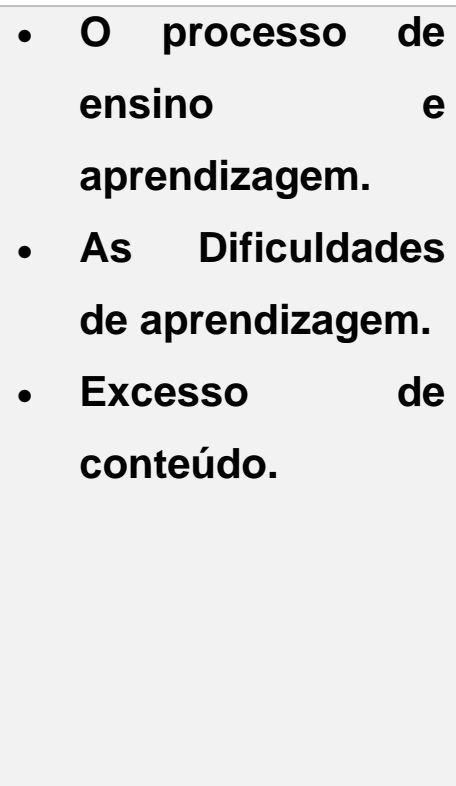 & $\begin{array}{l}\text { "Vencer as } \\
\text { dificuldades que vão } \\
\text { aparecendo durante } \\
\text { o ano letivo, as } \\
\text { dificuldades de } \\
\text { aprendizagem, os } \\
\text { alunos têm } \\
\text { dificuldades na } \\
\text { interpretação, é } \\
\text { difícil dar conta de } \\
\text { todo o conteúdo." }\end{array}$ & 13 & $\begin{array}{l}\text { Frustração, } \\
\text { angústia, } \\
\text { sobrecarregado. }\end{array}$ \\
\hline $\begin{array}{l}\text { - A falta de limites. } \\
\text { - As dificuldades } \\
\text { de aprendizagem. }\end{array}$ & $\begin{array}{l}\text { "É um desafio } \\
\text { quando tem crianças } \\
\text { muito agitadas na } \\
\text { sala de aula, e os } \\
\text { problemas de } \\
\text { aprendizagem." }\end{array}$ & 14 & $\begin{array}{l}\text { Estava bem } \\
\text { segura, falou com } \\
\text { firmeza, se } \\
\text { preocupa com a } \\
\text { aprendizagem } \\
\text { das crianças. }\end{array}$ \\
\hline - Dificuldades & "Lá no Rio de & 15 & Falou \\
\hline
\end{tabular}




\begin{tabular}{|c|c|c|}
\hline aprendizagem. & $\begin{array}{l}\text { Janeiro, de onde eu } \\
\text { vim e lecionava, tem } \\
\text { problemas das } \\
\text { superlotação são } \\
\text { salas de aula, a falta } \\
\text { de infraestrutura. As } \\
\text { escolas a } \\
\text { pichadas devido ao } \\
\text { meio, a comunidade, } \\
\text { são sujas, pichadas, } \\
\text { quebradas! } \\
\text { Pinhalzinho, em SC, } \\
\text { a realidade é outra, } \\
\text { não tem esses } \\
\text { problemas! A turma } \\
\text { foi heterogênea, } \\
\text { houve alguns casos } \\
\text { de dificuldade de } \\
\text { aprendizagem, mas } \\
\text { não graves. } \\
\text { Psicopedagogia } \\
\text { ajuda a lidar com } \\
\text { essas situações." }\end{array}$ & $\begin{array}{l}\text { segurança, pois } \\
\text { tem } \\
\text { conhecimento e } \\
\text { sabe como lidar } \\
\text { com cada } \\
\text { problema. }\end{array}$ \\
\hline
\end{tabular}

Fonte: $A$ autora. TMP./MWW.NUCLEDOCONHECMENTO.COM.BR 
dificuldades de aprendizagem que foram mencionadas várias vezes. Porém, 53,33\% dos professores relataram que o maior desafio é a dificuldade de aprendizagem.

De acordo com Silva e Sartori (2012), a formação do professor é considerada de fundamental importância para 0 processo de qualificação do ensino e da aprendizagem, a qual deve qualificar para o desempenho de suas atividades docentes. Os cursos de licenciatura, as formações universitárias também precisam passar por algum aperfeiçoamento, pois é imprescindível o conhecimento que se adquire da universidade, para uma formação de qualidade. Sabe-se que o enfoque de algumas universidades é atender a demanda de uma sociedade capitalista, uma clientela etilista. Por esta razão, a educação, de modo geral, tem sido refém de imposições do sistema capitalista, do Estado, que decide como e o que fazer. As escolas, desta forma, acabam se tornando apenas meios intermediários, ambientes de aprendizagem onde aprendem aquilo que a sociedade necessita para que este sistema capitalista se mantenha no país.

Segundo Silva e Sartori (2012), cabe ao professor mudar esta realidade, com o desafio de inovar, ser pesquisador, usar a sua criatividade para conquistar as crianças e através de sua prática pedagógica, procurar desenvolver as diversas inteligências, competências ou habilidades intelectuais da criança. A partir de seus métodos de ensino o professor pode ou não criar condições de ensino e aprendizagem, levando a motivação dos alunos ou não. É importante o professor refletir constantemente sobre sua prática pedagógica, para que seja realmente eficiente.

Conforme a Tabela 3, pode-se analisar quais são as dificuldades de aprendizagem no ponto de vista dos professores das duas escolas. A pergunta realizada foi: "Existem dificuldades de aprendizagem na sua turma? Quais?" 
Tabela 3- Análise temática: existem dificuldades de aprendizagem em sua turma? Quais?

Temática:

- Déficit de atenção.
Fala do Professor:

"Sim. Deficiência

moderada leve, tem crianças da APAE, (Associação de Pais e Amigos

Excepcionais), alguns frequentam SAED (Serviço de

Atendimento

Especializado), uns tem retardo mental, deficiência mental leve, déficit de atenção. Muitas crianças, não se sabe o que tem, pois elas são encaminhadas e não se tem mais resultado. Neste Bairro Maria Terezinha, existem muitas famílias pobres e com problemas e algumas famílias, quando o filho é encaminhado para diagnosticar seu

\section{Sequência: Enunciação:}

Frases de

partida

espontânea...

Perturbação

com tantos

problemas,

preocupação.

Frases que

mostram

indignação.

Mostra

satisfação em

sua fala. 


\begin{tabular}{|c|c|c|c|}
\hline & $\begin{array}{l}\text { problema de } \\
\text { aprendizagem, } \\
\text { quando a família } \\
\text { precisa gastar para } \\
\text { acompanhamento } \\
\text { médico, psicólogo, } \\
\text { desistem e tudo para } \\
\text { por aí mesmo. Outros } \\
\text { que são } \\
\text { encaminhados para } \\
\text { neurologista são } \\
\text { tratados } \\
\text { progrediram na } \\
\text { aprendizagem!" }\end{array}$ & & \\
\hline 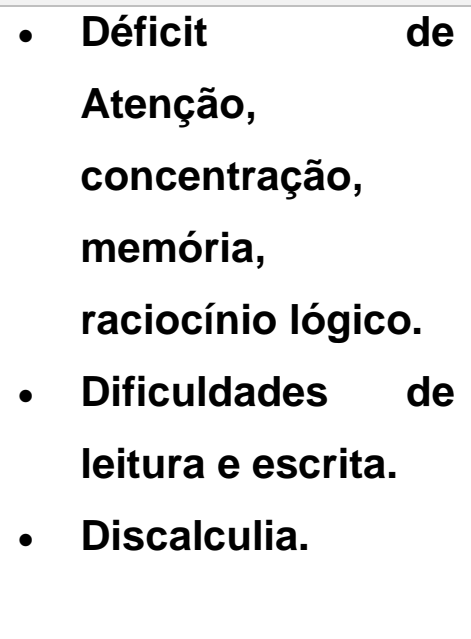 & $\begin{array}{l}\text { "Sim. Nas turmas em } \\
\text { que atuo atualmente } \\
\text { tem dificuldades de } \\
\text { atenção } \\
\text { concentração, } \\
\text { memória, raciocínio } \\
\text { lógico, dificuldade de } \\
\text { leitura e escrita, } \\
\text { discalculia." }\end{array}$ & 2 & $\begin{array}{l}\text { Frases secas e } \\
\text { curtas, sem } \\
\text { muitos detalhes. }\end{array}$ \\
\hline $\begin{array}{l}\text { - Agressividade. } \\
\text { - Falta de atenção, } \\
\text { concentração, } \\
\text { memória. }\end{array}$ & $\begin{array}{l}\text { "Sim. Tem problemas } \\
\text { mentais, } \\
\text { agressividade, falta } \\
\text { de atenção, } \\
\text { concentração, } \\
\text { memória, existindo } \\
\text { na turma cinco } \\
\text { alunos com laudo }\end{array}$ & 3 & $\begin{array}{l}\text { Frases que } \\
\text { mostram } \\
\text { angústia, } \\
\text { preocupação, } \\
\text { estresse } \\
\text { emocional. }\end{array}$ \\
\hline
\end{tabular}




$$
\begin{aligned}
& \text { médico, que usam } \\
& \text { remédio controlado e } \\
& \text { que estão sendo } \\
& \text { tratados. Eles estão } \\
& \text { melhorando, um } \\
& \text { deles é deficiente } \\
& \text { visual, tem } \\
& \text { deficiência mental } \\
& \text { leve e moderada. } \\
& \text { Estes alunos não } \\
& \text { acompanham a } \\
& \text { turma, tem aula de } \\
& \text { reforço com uma } \\
& \text { pedagoga. Eles não } \\
& \text { acompanham } 0 \\
& \text { conteúdo e as } \\
& \text { atividades, deixam as } \\
& \text { atividades } \\
& \text { incompletas, mas é } \\
& \text { feito o possível para } \\
& \text { que não sejam } \\
& \text { excluídos da turma. } \\
& \text { Os colegas também } \\
& \text { ajudam. As crianças } \\
& \text { são ocupadas com } \\
& \text { atividades extras que } \\
& \text { dominam, que são do } \\
& \text { nível deles e a } \\
& \text { aprendizagem delas } \\
& \text { avança muito. Isso é } \\
& \text { gratificante. Muitos }
\end{aligned}
$$




\begin{tabular}{|c|c|c|c|}
\hline & $\begin{array}{l}\text { deles não têm ajuda } \\
\text { dos pais, só a } \\
\text { escola." }\end{array}$ & & \\
\hline $\begin{array}{l}\text { - Agressividade } \\
\text { - Dificuldades de } \\
\text { matemática. } \\
\text { Dificuldades de } \\
\text { leitura e escrita. } \\
\text { - Dificuldades de } \\
\text { atenção. }\end{array}$ & $\begin{array}{lr}\text { "Sim. } & \text { Como } \\
\text { professora } & \text { de } \\
\text { reforço, tem várias } \\
\text { dificuldades de } \\
\text { aprendizagem, todas } \\
\text { que existem na } \\
\text { escola, atendo todos } \\
\text { os casos." }\end{array}$ & 4 & $\begin{array}{l}\text { Frases calmas, } \\
\text { com risos, } \\
\text { mostra-se bem } \\
\text { preocupada, } \\
\text { com tal } \\
\text { compromisso. }\end{array}$ \\
\hline $\begin{array}{l}\text { - Dificuldades na } \\
\text { leitura e escrita, } \\
\text { - Dificuldades de } \\
\text { matemática. }\end{array}$ & 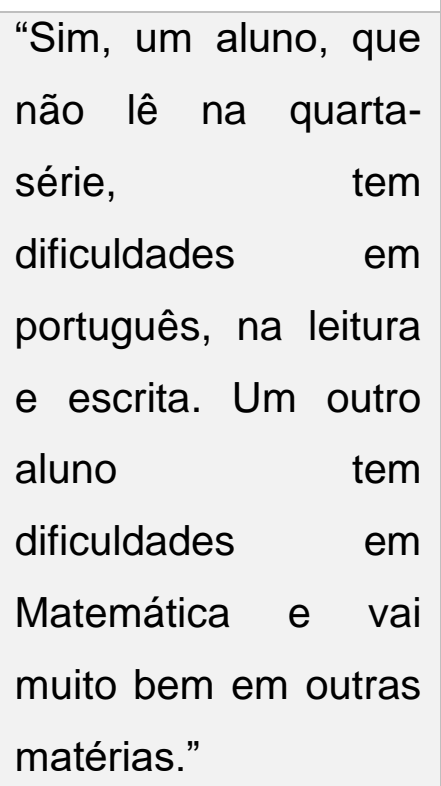 & 5 & $\begin{array}{l}\text { Frases curtas, } \\
\text { secas, fala sem } \\
\text { muita } \\
\text { explicação. }\end{array}$ \\
\hline $\begin{array}{l}\text { - Dificuldades de } \\
\text { leitura e escrita. } \\
\text { - Déficit de atenção. }\end{array}$ & $\begin{array}{l}\text { "Sim. Tem um aluno } \\
\text { com Síndrome de } \\
\text { Down, outros que } \\
\text { ainda não sabem ler } \\
\text { e escrever certo, com } \\
\text { dificuldades de } \\
\text { concentração, um }\end{array}$ & 6 & $\begin{array}{l}\text { Fala como se } \\
\text { fosse um } \\
\text { desabafo, se } \\
\text { mostra } \\
\text { preocupado. }\end{array}$ \\
\hline
\end{tabular}




\begin{tabular}{|c|c|c|c|}
\hline & $\begin{array}{l}\text { que só quer brincar. } \\
\text { O material escolar } \\
\text { para ele é um } \\
\text { brinquedo. Eles vão } \\
\text { às aulas de reforço, o } \\
\text { professor precisa } \\
\text { buscar as atividades } \\
\text { para eles do nível } \\
\text { deles." }\end{array}$ & & \\
\hline $\begin{array}{l}\text { - Não tem } \\
\text { problemas de } \\
\text { aprendizagem, } \\
\text { pois é bem- } \\
\text { informada e sabe } \\
\text { como contornar e } \\
\text { solucionar os } \\
\text { problemas na sala } \\
\text { de aula. }\end{array}$ & $\begin{array}{l}\text { "Este ano não tenho } \\
\text { problemas de } \\
\text { aprendizagem. O } \\
\text { primeiro ano é lúdico, } \\
\text { as crianças precisam } \\
\text { se alfabetizar até o } \\
\text { terceiro ano, e até } \\
\text { então ninguém pode } \\
\text { reprovar. Cada } \\
\text { criança tem o seu } \\
\text { tempo de aprender, } \\
\text { precisa de estímulo } \\
\text { para despertar. Os } \\
\text { pais têm uma } \\
\text { parceria muito grande } \\
\text { nesta escola, 99\% } \\
\text { dos pais auxiliam, } \\
\text { participam da escola } \\
\text { e os problemas são } \\
\text { resolvidos. Eles vêm } \\
\text { conhecer a escola, } \\
\text { conversar com os }\end{array}$ & 7 & $\begin{array}{l}\text { Frases curtas, } \\
\text { sem muita } \\
\text { explicação, } \\
\text { mostra } \\
\text { segurança no } \\
\text { que fala. Não se } \\
\text { mostra } \\
\text { preocupada com } \\
\text { as dificuldades } \\
\text { de } \\
\text { aprendizagem. }\end{array}$ \\
\hline
\end{tabular}




$$
\begin{aligned}
& \text { professores e assim, } \\
& \text { entendem como } \\
& \text { funciona o trabalho. } \\
& \text { No primeiro ano, } \\
& \text { quando o aluno não } \\
& \text { aprende a ler e } \\
& \text { escrever, não é um } \\
& \text { problema de } \\
& \text { aprendizagem, é falta } \\
& \text { de estímulo, de } \\
& \text { material, treino, } \\
& \text { dedicação, temos } \\
& \text { que respeitar a } \\
& \text { maturidade do aluno. } \\
& \text { Quando há um } \\
& \text { problema os pais são } \\
& \text { chamados, eles } \\
& \text { ajudam em casa, } \\
& \text { sempre dá certo } \\
& \text { quando chamam os } \\
& \text { pais, eles vêm } \\
& \text { conhecer o trabalho } \\
& \text { dos professores, e } \\
& \text { assim, tem dado } \\
& \text { muito resultado, isso } \\
& \text { é interessante, fico } \\
& \text { feliz quando os pais } \\
& \text { vêm conhecer como } \\
& \text { ocorre o processo de } \\
& \text { ensino } \\
& \text { e } \\
& \text { aprendizagem do seu }
\end{aligned}
$$




\section{filho."}

- Dislexia, disgrafia. "Tem quatro alunos 8

- DDA, (Déficit de repetentes, com Atenção).

- Hiperatividade.

muitas dificuldades, um deles tem laudo médico, eles têm dislexia, disgrafia, DDA, hiperatividade, outro não está alfabetizado, tem laudo. Outro aluno é autista, não fala, com deficiência mental tem diagnóstico de Transtorno Global de Desenvolvimento com Espectro Autista Atraso no

Desenvolvimento Neuropsicomotor. Esse aluno vai na APAE (Associação de Pais e Amigos Excepcionais) e no SAEDE (Serviço de Atendimento de Educação Especial). O SAEDE trabalha com turmas
Desabafou, se mostrou angustiada diante da situação, frases que mostram angústia, desânimo. 


$$
\begin{aligned}
& \text { pequenas, } \\
& \text { funcionando na } \\
& \text { APAE, } \quad \text { com } \\
& \text { professores de } \\
& \text { Educação Especial, } \\
& \text { que tem como } \\
& \text { objetivo desenvolver } \\
& \text { a Psicomotricidade, } \\
& \text { concentração, } \\
& \text { lateralidade, memória } \\
& \text { etc. O terceiro ano é } \\
& \text { considerado o "APC" } \\
& \text { da alfabetização, até } \\
& \text { então deverá estar } \\
& \text { alfabetizado, e dali } \\
& \text { em diante a lei prevê } \\
& \text { que o aluno poderá } \\
& \text { reprovar. Quando o } \\
& \text { aluno não aprende, } \\
& \text { fala-se com os pais, } \\
& \text { encaminha-se a } \\
& \text { criança para a aula } \\
& \text { de reforço. É uma } \\
& \text { angústia, pois } 0 \\
& \text { Conselho de Classe } \\
& \text { às vezes não } \\
& \text { colabora muito na } \\
& \text { hora da decisão, com } \\
& \text { os alunos deficientes } \\
& \text { que não progridem. } \\
& \text { Isso é complicado, }
\end{aligned}
$$




\begin{tabular}{|c|c|c|c|}
\hline & $\begin{array}{l}\text { tem } \\
\text { excepcionais que não } \\
\text { reagem, não } \\
\text { progridem em nada, } \\
\text { não vê resultado } \\
\text { nenhum." }\end{array}$ & & \\
\hline $\begin{array}{l}\text { - Dificuldades de } \\
\text { leitura, em } \\
\text { português. } \\
\text { - Falta de atenção. } \\
\text { - Dificuldades de } \\
\text { Matemática. }\end{array}$ & $\begin{array}{l}\text { "Sim. Tem alunos } \\
\text { com dificuldades na } \\
\text { leitura, deficiência } \\
\text { mental, falta de } \\
\text { atenção. De quarenta } \\
\text { e três alunos, tem } \\
\text { treze com } \\
\text { dificuldades de } \\
\text { aprendizagem em } \\
\text { Matemática } \\
\text { português. Muitos } \\
\text { têm dificuldades } \\
\text { passageiras, e então } \\
\text { o aluno é } \\
\text { encaminhado para as } \\
\text { aulas de reforço." }\end{array}$ & 9 & $\begin{array}{l}\text { Frases com } \\
\text { muita seriedade, } \\
\text { desconfiança, } \\
\text { mas falou seus } \\
\text { problemas que } \\
\text { encontra na sala } \\
\text { de aula. Frases } \\
\text { sem muito } \\
\text { detalhe. }\end{array}$ \\
\hline $\begin{array}{l}\text { - Problemas de } \\
\text { alfabetização, } \\
\text { leitura e escrita }\end{array}$ & $\begin{array}{l}\text { "Sim. Tem problemas } \\
\text { de alfabetização, } \\
\text { alunos com } \\
\text { diagnóstico, mas tem } \\
\text { o segundo professor. } \\
\text { É preciso dar } \\
\text { atividades pegar } \\
\text { diferenciadas e pritor } \\
\text { um aluno monita }\end{array}$ & 10 & $\begin{array}{l}\text { Frases curtas, } \\
\text { se mostrou } \\
\text { comprometida, } \\
\text { com as } \\
\text { dificuldades de } \\
\text { aprendizagem, } \\
\text { como se já } \\
\text { estivesse o } \\
\text { fazendo a }\end{array}$ \\
\hline
\end{tabular}




\begin{tabular}{|c|c|c|c|}
\hline & $\begin{array}{l}\text { para auxiliar os } \\
\text { colegas. Problemas } \\
\text { de escrita e leitura, } \\
\text { fazem aula de reforço } \\
\text { que a escola oferece. } \\
\text { A tarde tem uma } \\
\text { turma com duas } \\
\text { crianças } \\
\text { dependentes que } \\
\text { precisa trocar a } \\
\text { fralda, o segundo } \\
\text { professor é que faz } \\
\text { isso." }\end{array}$ & & $\begin{array}{l}\text { possível para } \\
\text { superar as } \\
\text { dificuldades de } \\
\text { aprendizagem. }\end{array}$ \\
\hline $\begin{array}{l}\text { - Dificuldades de } \\
\text { leitura e escrita }\end{array}$ & 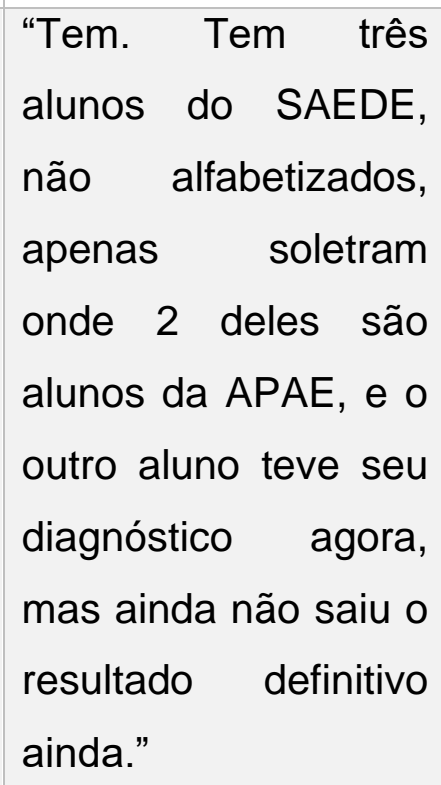 & 11 & $\begin{array}{l}\text { Falou com } \\
\text { calma, } \\
\text { segurança. }\end{array}$ \\
\hline $\begin{array}{l}\text { - Dificuldade de } \\
\text { leitura, escrita, } \\
\text { interpretação } \\
\text { - Dificuldades de } \\
\text { atenção }\end{array}$ & $\begin{array}{l}\text { "Sim. Dificuldades de } \\
\text { leitura, atenção, da } \\
\text { escrita, o saber } \\
\text { interpretar, pois se } \\
\text { nãorabem } \\
\text { interpretar, não } \\
\text { saberão o restante." }\end{array}$ & 12 & $\begin{array}{l}\text { Frases curtas, } \\
\text { sem detalhes, foi } \\
\text { direta. }\end{array}$ \\
\hline
\end{tabular}


- Dificuldade de "Sim. Tem um aluno 13 escrita, leitura.

- Dificuldades fala. que não consegue frases, de produzir dificuldades na fala, não é deficiente $\mathrm{e}$ nem tem laudo."
- Dificuldades matemática,

- Dificuldades leitura e escrita.

de "Dificuldade de 14

Matemática, de

de leitura e escrita."

\begin{tabular}{|c|c|c|c|}
\hline leitura e escrita. & & & ansiosa ao falar. \\
\hline $\begin{array}{l}\text { Dificuldades de escrita e } \\
\text { leitura }\end{array}$ & $\begin{array}{lr}\text { "Sim. Teve cinco } \\
\text { casos, } \\
\text { dificuldades de } \\
\text { aprendizagem, } \\
\text { dificuldades } \\
\text { leitura, escrita, mas } \\
\text { foi encaminhado para } \\
\text { um neurologista, para } \\
\text { fonoaudióloga, aula } \\
\text { de reforço." }\end{array}$ & 15 & $\begin{array}{l}\text { Falou com } \\
\text { rapidez, } \\
\text { ansiedade, não } \\
\text { querendo dar } \\
\text { muitos detalhes. }\end{array}$ \\
\hline
\end{tabular}

Fonte: autora.

Conforme os dados, a maior dificuldade encontrada pelos professores é a dificuldade de leitura e escrita, respondida por onze pessoas das quinze entrevistadas, correspondendo a $73 \%$. Pois conforme seus relatos, todo processo de aprendizagem da criança depende da escrita e leitura na escola. Foi relatado a falta de atenção, dificuldade de concentração e memória, respondida por oito educadores, que corresponde a $53,3 \%$. Pois sem atenção a criança não consegue desenvolver as demais habilidades que envolvem raciocínio, concentração, 
interpretação etc. A criança precisa de boa memória, concentração para conseguir armazenar as informações passadas a cada dia na escola.

De acordo com cinco professores, correspondente a $30 \%$ dos entrevistados, as dificuldades de matemática são consideradas a maior dificuldade de aprendizagem, que seriam as capacidades lógico - matemáticas, os cálculos, raciocínio lógico, a compreensão de números e suas quantidades. Alguns professores relataram outros fatores, como: agressividade, dificuldades na fala, hiperatividade, mas com menos proporção de casos. A próxima tabela mostra as atitudes tomadas em cada situação de dificuldade de aprendizagem, na opinião de cada profissional. A pergunta foi: "O que o professor faz diante das dificuldades de aprendizagem?"

Como mostra a Tabela 4, Análise Temática das Atitudes Valorizadas e Tabela 5 das Atitudes Rejeitadas: São Atitudes Adotadas pelo Professor Diante das Dificuldades de Aprendizagem.

Tabela 4 - Análise das atitudes valorizadas do professor diante das dificuldades de aprendizagem- o que o professor faz diante das dificuldades de aprendizagem?

\begin{tabular}{|c|c|c|c|c|}
\hline Categorias: & \multicolumn{3}{|c|}{$\begin{array}{l}\text { Componentes (atitude positivas do } \\
\text { professor): }\end{array}$} & Frequências: \\
\hline Cobrança & Cobrar dos & alunos. & & 1 \\
\hline Criatividade & $\begin{array}{l}\text { Adaptar } \\
\text { Tenta } \\
\text { Faz } \\
\text { Trabalhar } \\
\text { Sair } \\
\text { Fazer } \\
\text { Usar } \\
\text { Trabalhar } \\
\text { Fazer } \\
\text { Usar }\end{array}$ & $\begin{array}{l}\text { as } \\
\text { de } \\
\text { atividades } \\
\text { com formas } \\
\\
\text { da } \\
\text { a } \\
\text { os } \\
\text { jogos, } \\
\text { em colegas } \\
\text { desen }\end{array}$ & $\begin{array}{r}\text { atividades. } \\
\text { tudo. } \\
\text { lúdicas. } \\
\text { diferentes. } \\
\text { sala. } \\
\text { visitas. } \\
\text { informática. } \\
\text { grupos. } \\
\text { ajudar. } \\
\text { etc. }\end{array}$ & $\begin{array}{l}1 \\
3 \\
2 \\
7 \\
1 \\
1 \\
1 \\
1 \\
2 \\
1\end{array}$ \\
\hline
\end{tabular}




\begin{tabular}{|c|c|c|}
\hline & $\begin{array}{lrrr}\text { Trabalha } & \text { com } & 0 & \begin{array}{r}\text { concreto } \\
\text { leitura. }\end{array} \\
\text { Incentivar } & & \text { a } & \begin{array}{r}\text { leiretar. } \\
\text { Ensinar }\end{array} \\
\text { Trabalhar separado } & \text { com } & & \text { quem tem } \\
\text { dificuldades } & \text { na } & & \text { aprendizagem. } \\
\text { Usar outro material. } & & \end{array}$ & $\begin{array}{l}3 \\
2 \\
1 \\
1 \\
1\end{array}$ \\
\hline Compromisso & 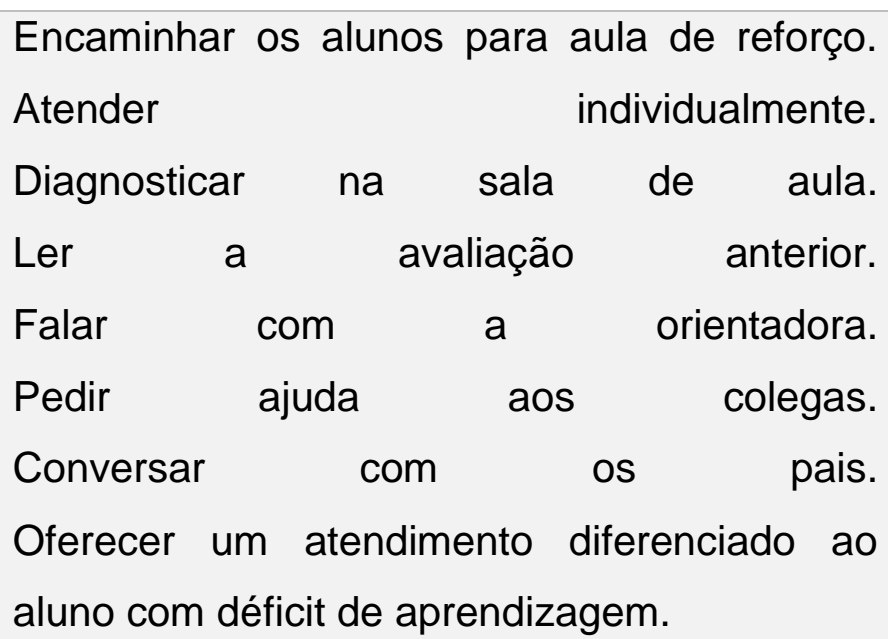 & $\begin{array}{l}1 \\
3 \\
1 \\
1 \\
1 \\
1 \\
1 \\
1 \\
1\end{array}$ \\
\hline Persistência & $\begin{array}{lrr}\text { Faz um } & \text { eterno } & \text { recomeço. } \\
\text { Insistir } & & \text { incansavelmente. } \\
\text { Se } & \text { dedicar. } \\
\text { Trabalhar o tempo todo. } & \end{array}$ & $\begin{array}{l}1 \\
1 \\
1 \\
1\end{array}$ \\
\hline Responsabilidade & $\begin{array}{l}\text { É analisado se vale a pena reter ou não o } \\
\text { aluno. } \\
\text { Faz } \quad 0 \quad \text { que } \\
\text { Procurar é } \\
\text { Dar uma atenção maior ao aluno com } \\
\text { dificuldades } \\
\text { Fazer com que o aluno aprenda... }\end{array}$ & $\begin{array}{l}1 \\
1 \\
1 \\
21\end{array}$ \\
\hline
\end{tabular}

Fonte: A autora. 
Tabela 5- Análise das atitudes rejeitadas do professor diante das dificuldades de aprendizagem

\begin{tabular}{|l|l|l|}
\hline Categorias & Componentes: (atitudes negativas) & Frequências \\
\hline $\begin{array}{l}\text { Falta } \\
\text { esperança }\end{array}$ & $\begin{array}{l}\text { "Impossível dar atenção individual com } \\
\text { qualidade." } \\
\text { "Se tiver que reprovar, reprovar!” }\end{array}$ & 1 \\
\hline Insegurança & "A escola não sabe o que fazer!" & 1 \\
\hline Desafio & "O professor fica preocupado!” & 1 \\
\hline
\end{tabular}

Fonte: A Autora.

Referente as atitudes e decisões tomadas pelos educadores perante as dificuldades de aprendizagem, constatou-se que os educadores tentam solucionar os problemas ou dificuldades diversas encontradas em suas turmas, buscando diferentes estratégias e metodologias para que a criança supere os mesmos, durante o ano letivo. Dentro de suas capacidades e habilidades profissionais, usam sua criatividade e conhecimento, embora não ser o mais adequado para a situação em alguns momentos. Os docentes mostraram que tentam diversas estratégias, fazem atividades diferenciadas, trabalham o lúdico, o concreto etc. Alguns professores responderam que encaminham a criança às aulas de reforço, são comprometidos, conversam com os pais, pedem ajuda aos colegas, orientadores das escolas, procuram alguma maneira para minimizar os déficits de aprendizagem. Demonstraram também que são persistentes, insistem incansavelmente, fazem um eterno recomeço, para que a criança tenha a oportunidade de rever o que ainda não conseguiu aprender.

Percebe-se que há muitas dúvidas quanto à forma mais adequada de agir, para que a criança supere as Dificuldades de Atenção, as dificuldades de Matemática e de Leitura e Escrita. Algumas pessoas entrevistadas mostram-se inseguras, pouco esperançosas, atuam com frieza no final das respostas. Há bastante falta de informação e insegurança na prática pedagógica, no que tange as dificuldades de aprendizagem. O educador tem como principal desafio, a busca constante do 
conhecimento, ser um eterno pesquisador sobre os assuntos relacionados às dificuldades de aprendizagem, para saber qual a melhor estratégia, ou prática pedagógica é mais apropriada para cada momento.

Perrenoud (2004) afirma que a escola não deve ignorar os problemas de aprendizagem e que é necessário compreender, que muitas crianças não estão espontaneamente em condições para aprender. Os professores devem fazer a sua parte, tomar medidas apropriadas para cada caso, que são da ordem da relação, de clima, da palavra, e do não verbal, oferecer respostas adequadas conforme cada situação.

Segundo Maturana e Rezepka, (2001) a formação humana da criança deve ter as condições que guiam e a apóiam em seu crescimento como um ser capaz de viver no autorrespeito pelo outro que pode dizer não a si a partir de si mesma e cuja individualidade, identidade e confiança em si mesma não se fundamentam na oposição ou diferença com os outros, mas com o respeito por si mesmo, de modo que possa colaborar, pois não teme desaparecer na relação.

Conforme Maturada e Resepka (2001) as dificuldades não são de índole intelectual e nem relacionada à sua personalidade, mas surgem da negação do amor como espaço de convivência. As crianças são inteligentes e capacitadas em seu emocional, são distintas em suas preferências, curiosidades, no fazer e no pensar e têm histórias de vida diferentes. As semelhantes emoções têm efeitos distintos sobre a inteligência, o preconceito e os sentimentos negativos reduzem a inteligência em sala de aula, reforçando que só o amor amplia a inteligência.

Pode-se perceber que todos os professores estão preocupados e comprometidos com a educação de seus alunos, se preocupam muito com a aprovação de cada um. Porém, todos fazem o possível para ajudar as crianças que têm mais dificuldade, mas nem tudo está ao seu alcance. Na persistência das dificuldades de aprendizagem das crianças, no final do ano letivo, aprovam ou reprovam a mesma, consideram estes momentos de decisão bastante angustiante, preocupante, pois 
não recebem apoio ou orientação de profissionais especializados da área, deixando os sem resolução em algumas situações.

O ano em que foi realizada esta pesquisa foi numa época em que as escolas estavam se adaptando ao novo sistema de ensino, (2011), que seria de nove anos para o Ensino Fundamental dali em diante. Por isso, a última turma que ainda tinha a nomenclatura "série", não poderia reprovar, devido a sua idade, pois seriam inseridos no novo sistema de nove anos e perderiam assim, dois anos caso reprovassem, conforme Lei Parecer CNE-CEB N 11/ 2010, publicado em 09/12/ 2010, pela Resolução N 7/ 2010; que relata sobre as Diretrizes Nacionais para o Ensino Fundamental de Nove Anos, considerando os três primeiros anos, um ciclo de alfabetização e a avaliação de caráter processual, formativo e participativo, contínua, cumulativa e diagnóstica.

Naquela época, muitas dificuldades de aprendizagem eram despercebidas ou tratadas com pouco apoio ou sem orientação escolar. Os encaminhamentos aos profissionais especializados eram realizados apenas em casos de extrema necessidade, quando as crianças apresentavam Distúrbios de Neurodesenvolvimento, e não especificamente em casos de dificuldades de aprendizagem, conforme mostra a tabela a seguir:

Tabela 6 - Análise temática: o educador recebe apoio pedagógico ou alguma orientação sobre as dificuldades de aprendizagem?

\begin{tabular}{|c|c|c|c|}
\hline Temática: & Resposta do Professor: & Sequência: & Enunciado: \\
\hline $\begin{array}{l}\text { Falta de parceria } \\
\text { entre escola } x \text { pais. }\end{array}$ & $\begin{array}{l}\text { "A direção da escola } \\
\text { encaminha os casos para }\end{array}$ & 1 & $\begin{array}{l}\text { Frase espontânea, } \\
\text { desenvolveu fácil }\end{array}$ \\
\hline $\begin{array}{lr}\text { Famílias } & \text { muito } \\
\text { carentes, } & \text { sem } \\
\text { condições } & \text { de } \\
\text { seguir } & \text { um } \\
\text { tratamento } & \end{array}$ & $\begin{array}{l}\text { o Posto de Saúde, mas a } \\
\text { família não apoia muito, } \\
\text { não dá importância, não } \\
\text { faz muita questão de } \\
\text { investir num tratamento, }\end{array}$ & & $\begin{array}{l}\text { sua fala, e com } \\
\text { muita segurança. } \\
\text { Mostrou frustração, } \\
\text { angústia. }\end{array}$ \\
\hline
\end{tabular}




\begin{tabular}{|c|c|c|c|}
\hline $\begin{array}{l}\text { adequado e de } \\
\text { qualidade. } \\
\text { participam } \\
\text { pouco da escola. }\end{array}$ & $\begin{array}{l}\text { não se interessam por } \\
\text { ajudar seu filho. Os pais } \\
\text { pensam que a escola é } \\
\text { que deve resolver esses } \\
\text { problemas e não eles. } \\
\text { Pensam que os } \\
\text { problemas de } \\
\text { aprendizagem são } \\
\text { genéticos, hereditários. É } \\
\text { bem complicado lidar } \\
\text { com esses casos, muitas } \\
\text { vezes os alunos } \\
\text { escondem os recados } \\
\text { dos professores aos pais, } \\
\text { e os pais simplesmente } \\
\text { nem aparecem na } \\
\text { escola." }\end{array}$ & & \\
\hline $\begin{array}{ll}\text { Falta } & \text { de } \\
\text { profissionais } & \\
\text { especializados } & \\
\text { para atender os } \\
\text { casos. }\end{array}$ & "Ninguém vem ajudar." & 2 & $\begin{array}{l}\text { Falou com frase } \\
\text { curta e direta. }\end{array}$ \\
\hline $\begin{array}{l}\text { Falta } \\
\text { profissionais } \\
\text { especializados } \\
\text { para atender os } \\
\text { casos. Falta de } \\
\text { parceria com o } \\
\text { setor da Saúde do } \\
\text { município, para } \\
\text { orientação. Muita }\end{array}$ & $\begin{array}{l}\text { "A escola ajuda, os pais } \\
\text { colaboram muito pouco, } \\
\text { deveria ter um grupo } \\
\text { pedagógico para ajudar, } \\
\text { a assistência social do } \\
\text { município poderia ajudar } \\
\text { as famílias, os médicos, } \\
\text { neurologistas poderiam } \\
\text { ajudar, orientar os }\end{array}$ & 3 & $\begin{array}{l}\text { Frases que } \\
\text { mostram } \\
\text { preocupação, } \\
\text { decepção no } \\
\text { trabalho como } \\
\text { professor, se sente } \\
\text { desamparado. }\end{array}$ \\
\hline
\end{tabular}


pobreza no bairro. professores. A semente é a família, as famílias deste bairro onde se localiza esta escola são muito pobres, e com muitos problemas. Uma coisa que dificulta muito a aprendizagem, a aula é a disparidade de idade que tem nas turmas, muitos alunos vem de fora, são transferidos de longe, e isso prejudica a turma."

Falta
profissionais

de "Não. Não tem ajuda. A 4 diretora atende um aluno especializados para atender casos. 


\begin{tabular}{|c|c|c|c|}
\hline & $\begin{array}{l}\text { quantidade de alunos } \\
\text { para atender. Faltam } \\
\text { profissionais para } \\
\text { atender esses casos." }\end{array}$ & & \\
\hline $\begin{array}{l}\text { Falta profissionais } \\
\text { para atender esses } \\
\text { casos. }\end{array}$ & $\begin{array}{l}\text { "Sim, a escola ajuda } \\
\text { nesses cursos, e assim } \\
\text { conseguimos mais } \\
\text { informações. Os casos } \\
\text { são resolvidos pela } \\
\text { escola. A partir do } \\
\text { conhecimento que temos } \\
\text { e das informações, é } \\
\text { visto o que fazer, que } \\
\text { atividades pode-se dar } \\
\text { em cada caso." }\end{array}$ & 6 & $\begin{array}{l}\text { Frases que omitem } \\
\text { a verdade, } \\
\text { parecem insegura } \\
\text { e tentam esconder } \\
\text { a realidade. Não } \\
\text { quer se expor, e } \\
\text { nem comprometer } \\
\text { ninguém da sua } \\
\text { escola. }\end{array}$ \\
\hline $\begin{array}{l}\text { Falta profissionais } \\
\text { para atender esses } \\
\text { casos, alguns } \\
\text { educadores mais } \\
\text { informados } \\
\text { conseguem } \\
\text { encaminhar seus } \\
\text { alunos, depende } \\
\text { da formação e } \\
\text { conhecimento do } \\
\text { educador. }\end{array}$ & $\begin{array}{l}\text { "Sim, os pais desta } \\
\text { escola colaboram muito, } \\
\text { os alunos são } \\
\text { encaminhados. Chama- } \\
\text { se a família, muitos } \\
\text { fazem o que a escola } \\
\text { pede, continuam o } \\
\text { tratamento, colaboram e } \\
\text { vê-se que em muitos } \\
\text { casos, o remédio ajuda, } \\
\text { pois devolve atenção. É } \\
\text { conversado com o } \\
\text { orientador pedagógico da } \\
\text { escola, o SAED orienta, } \\
\text { os pais colaboram. Os } \\
\text { pais geralmente apoiam, }\end{array}$ & 7 & $\begin{array}{l}\text { Parece ser sincera, } \\
\text { se mostra segura, } \\
\text { e parece estar } \\
\text { mais informada. } \\
\text { Sua formação de } \\
\text { psicopedagogia e } \\
\text { sua experiência lhe } \\
\text { ajudam. }\end{array}$ \\
\hline
\end{tabular}




\begin{tabular}{|c|c|c|c|}
\hline & $\begin{array}{l}\text { é preciso saber } \\
\text { argumentar estes casos } \\
\text { com a direção, com } \\
\text { sugestões a serem feitas } \\
\text { e não apenas se livrar do } \\
\text { problema." }\end{array}$ & & \\
\hline $\begin{array}{l}\text { Falta de } \\
\text { profissionais } \\
\text { especializados da } \\
\text { área para atender } \\
\text { os casos. }\end{array}$ & 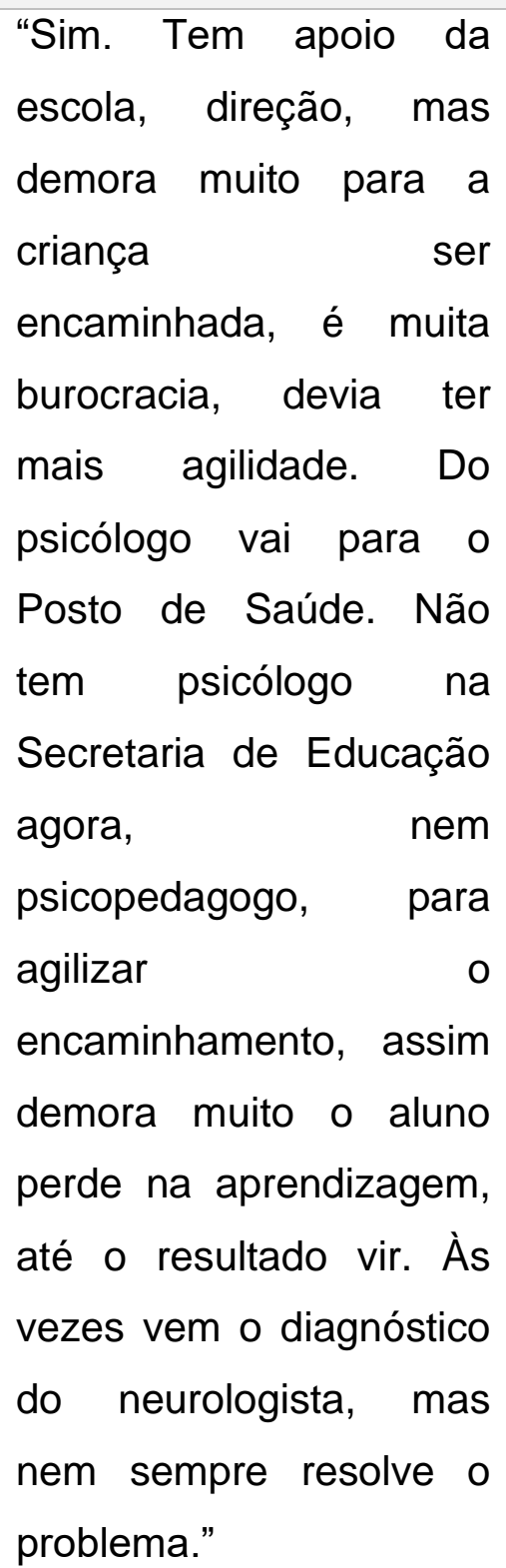 & 8 & $\begin{array}{l}\text { Se mostra } \\
\text { angustiado, muito } \\
\text { frustrado, se vê } \\
\text { desamparado sem } \\
\text { muita esperança. }\end{array}$ \\
\hline $\begin{array}{l}\text { A Diretora cumpre } \\
\text { função de } \\
\text { psicopedagoga, }\end{array}$ & $\begin{array}{l}\text { "A direção também } \\
\text { apoia, acompanha a } \\
\text { criança, a ver atividades }\end{array}$ & 9 & $\begin{array}{l}\text { Frases curtas, } \\
\text { rápidas e sem } \\
\text { muita explicação. }\end{array}$ \\
\hline
\end{tabular}

RC: 97780

Disponível em: https://www.nucleodoconhecimento.com.br/pedagogia/aprendizagem 


\begin{tabular}{|c|c|c|c|}
\hline $\begin{array}{l}\text { pois faltam } \\
\text { profissionais } \\
\text { especializados } \\
\text { nesta área. }\end{array}$ & $\begin{array}{l}\text { que se pode usar para } \\
\text { trabalhar com as } \\
\text { crianças." }\end{array}$ & & \\
\hline $\begin{array}{l}\text { Alguns } \\
\text { professores têm } \\
\text { pouca informação } \\
\text { sobre as } \\
\text { dificuldades de } \\
\text { aprendizagem, } \\
\text { falta profissionais } \\
\text { da área para } \\
\text { atender os casos. }\end{array}$ & $\begin{array}{l}\text { "A direção ajuda. Os pais } \\
\text { ajudam um pouco. Na } \\
\text { escola tem material a } \\
\text { respeito, mas falta tempo } \\
\text { para ler e estudar. } \\
\text { Cursos têm poucos, } \\
\text { sobre as dificuldades de } \\
\text { aprendizagem. Deveria } \\
\text { ter mais coisas práticas } \\
\text { de como trabalhar com } \\
\text { alunos com dificuldades, } \\
\text { para poder usar isso na } \\
\text { prática. É muito } \\
\text { complicado com vinte e } \\
\text { nove alunos, e os pais } \\
\text { não ajudam muito, eles } \\
\text { não sabem ajudar muito." }\end{array}$ & 10 & $\begin{array}{lr}\text { Parecia ser bem } \\
\text { sincero, falou com } \\
\text { segurança, e com } \\
\text { detalhes. } \\
\text { mostra } \\
\text { preocupado. }\end{array}$ \\
\hline $\begin{array}{lr}\text { A escola } & \text { tenta } \\
\text { ajudar, } & \text { mas } \\
\text { ninguém } & \text { sabe } \\
\text { ajudar da forma } \\
\text { adequada, faltam } \\
\text { profissionais da } \\
\text { área. }\end{array}$ & $\begin{array}{l}\text { "Da escola sim, a direção } \\
\text { ajuda e todos colaboram. } \\
\text { Tem o reforço, os pais } \\
\text { colaboram, todos são } \\
\text { interessados. Da escola } \\
\text { tem muita colaboração. A } \\
\text { secretaria de educação } \\
\text { não interfere em nada } \\
\text { disso." }\end{array}$ & 11 & $\begin{array}{l}\text { Frases curtas, } \\
\text { omite a verdade, } \\
\text { fala bastante } \\
\text { insegura. }\end{array}$ \\
\hline Itam & "Tem uma professora & 12 & $\mathrm{Se}$ \\
\hline
\end{tabular}




\begin{tabular}{|c|c|c|c|}
\hline $\begin{array}{l}\text { profissionais da } \\
\text { área para atender } \\
\text { os casos. }\end{array}$ & 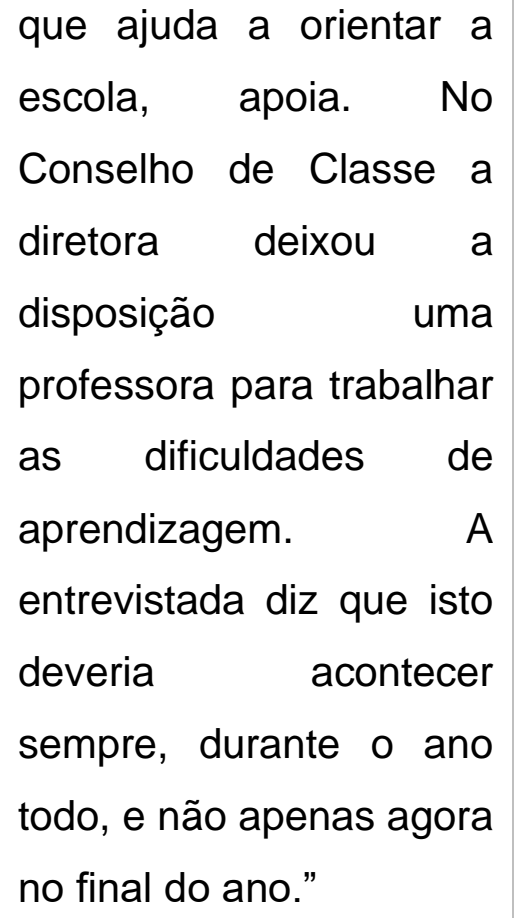 & & $\begin{array}{l}\text { sincera, falou com } \\
\text { tranquilidade, } \mathrm{e} \\
\text { segurança. }\end{array}$ \\
\hline $\begin{array}{l}\text { Cada professor } \\
\text { tenta fazer sua } \\
\text { parte, uma vez que } \\
\text { não tem } \\
\text { profissionais } \\
\text { especializados } \\
\text { para ajudar. }\end{array}$ & $\begin{array}{l}\text { "Não. A professora diz } \\
\text { que está se virando } \\
\text { sozinha, eles têm até o } \\
\text { 3 ano para se } \\
\text { alfabetizar, e por isso, as } \\
\text { dificuldades até então, } \\
\text { não são interpretadas } \\
\text { como um problema." }\end{array}$ & 13 & $\begin{array}{l}\text { Se mostrou bem } \\
\text { segura, } \\
\text { desenvolveu fácil } \\
\text { sua fala. }\end{array}$ \\
\hline $\begin{array}{l}\text { A escola } \\
\text { ajudar, } \\
\text { ninguém mas } \\
\text { ajudar da forma } \\
\text { adequada, faltam } \\
\text { profissionais da } \\
\text { área. }\end{array}$ & $\begin{array}{l}\text { "Sim. A escola ajuda, } \\
\text { todos ajudam e dão } \\
\text { apoio." }\end{array}$ & 14 & $\begin{array}{l}\text { Omite a verdade. } \\
\text { Frases curtas, } \\
\text { rápidas e sem } \\
\text { detalhes. }\end{array}$ \\
\hline $\begin{array}{l}\text { Falta profissionais } \\
\text { especializados. }\end{array}$ & $\begin{array}{l}\text { "A direção ajuda um } \\
\text { pouco, e a secretaria não } \\
\text { ajuda nada, ninguém }\end{array}$ & 15 & $\begin{array}{lr}\text { Frases } & \text { bem } \\
\text { seguras, curtas e } \\
\text { faladas } & \text { com }\end{array}$ \\
\hline
\end{tabular}


orienta."

mágoa.

Fonte: A Autora

Quanto ao apoio pedagógico ou orientação escolar nos casos de dificuldades de aprendizagem com crianças, vários fatores dificultam e comprometem o trabalho pedagógico do professor: pouca informação sobre o assunto, falta de apoio e orientação escolar para realizar os encaminhamentos aos profissionais especializados, distanciamento da família e a falta de profissionais na Secretaria da Educação para realizar este suporte de apoio e orientação ao professor. É fato que a direção da escola se preocupa, "ajuda do seu jeito, do seu ponto de vista", mas nem sempre da forma adequada, pois o que falta na verdade, são informações sobre o assunto e apoio de vários profissionais da área da Saúde para fazer os encaminhamentos necessários. Os professores formados em Psicopedagogia têm um olhar diferente diante das Dificuldades de Aprendizagem, o que influi muito na sua forma de conduzir a situação, de solucionar e avaliar a situação de Dificuldade de Aprendizagem.

Assim muitas dificuldades de aprendizagem passam despercebidas, muitos casos não são solucionados. São solucionados apenas alguns casos mais graves, quando vários problemas se repetiram vários anos, com vários professores e nem sempre se tem sucesso. Foi relatado sobre a falta de material pedagógico para auxiliar as crianças com dificuldades". Significa que falta variedade de jogos pedagógicos necessários, aspecto importante para o desenvolvimento intelectual da criança, e principal estratégia para superação das dificuldades de aprendizagem da criança.

Outra questão preocupante no ponto de vista de alguns profissionais, é o fato de que a "não reprovação", das crianças do primeiro ano e segundo ano e a avaliação descritiva por ser de caráter processual e formativa, pois a criança tem até o terceiro ano para se alfabetizar, sendo considerado como ciclo de alfabetização de acordo com as Diretrizes Curriculares Nacionais para o Ensino de Nove Anos, Lei Parecer CNE-CEB N 11/2010. Neste sentido, as dificuldades de alfabetização em alguns 
casos podem passar por despercebidas, não sendo consideradas como uma dificuldade de aprendizagem, pois tem tempo até 0 terceiro ano para a alfabetização, deixando os professores preocupados. É notável que as dificuldades de aprendizagem, conforme as respostas coletadas são consideradas de responsabilidade do professor, não havendo preocupação com a necessidade de encaminhamentos para profissionais da área para resolver ou minimizar as dificuldades de aprendizagem para estas turmas.

\section{ANÁLISE DOS DADOS}

Conforme o resultado da entrevista e dados coletados, o foco ficou centralizado na questão das dificuldades de aprendizagem apresentadas pelos educadores, conforme a sua visão de educador, constituindo um dos grandes desafios para a educação no momento contemporâneo. Portanto, as maiores dificuldades de aprendizagem apontadas foram: as Dificuldades na Leitura e Escrita, a Falta de Atenção e a Dificuldade em Matemática. A seguir, terá a descrição de cada uma, relatando quais as formas mais adequadas de superá-las, ou tratá-las.

\subsection{DIFICULDADE DE LEITURA E ESCRITA: DISLEXIA}

A dificuldade na Leitura e Escrita, dificuldades na alfabetização é considerada a maior dificuldade de aprendizagem presente nas escolas municipais do Ensino Fundamental, apontada pelos professores em 73\%, identificada como dislexia, segundo Salles e Parente (2008). O desenvolvimento dos processos de leitura e escrita estão relacionadas ao desenvolvimento de habilidades neuropsicológicas, a fatores biológicos/ maturacionais e psicossociais (familiares e escolares).

Salles e Parente (2008), explica a dislexia como um distúrbio que acontece em crianças com inteligência e habilidades sensoriais normais. A dislexia pode ser classificada como: fonológica (dificuldades de decodificar fonemas), de superfície, (dificuldade no nível ortográfico da informação) e mistas (quando o distúrbio acontece na decodificação fonológica e no processo lexical). A causa pode ser uma predisposição cerebral gerada por fatores biológicos em interação com o ambiente, 
causando uma disfunção nos componentes mentais usuais para ler e escrever, como o processamento fonológico, o uso da estrutura fonológica ou sonora da linguagem oral.

Para superar a dislexia segundo Salles et al (2004), podem ser feitas atividades escolares voltadas à decodificação, compreensão dos fonemas, a correspondência entre grafemas e fonemas, a análise de palavras em unidades fonológicas, ensinando a ler e escrever e explorar a compreensão do código fonológico. Portanto, é possível tratar as anomalias cerebrais através de estímulos ambientais ou por intervenções terapêuticas. No cérebro em crescimento, o tecido nervoso modela-se, o que é importante durante a intervenção, de acordo com Salles et al (2004).

Segundo Capellini et al (2007) a dislexia é familiar e hereditária, sendo estes um dos mais importantes fatores de risco, de $23 \%$ a $65 \%$ dos casos. De acordo com Capellini et al (2007, p. 375):

\begin{abstract}
Estudos de ligação e associação têm apontado várias regiões cromossômicas que podem conter genes candidatos à dislexia. Essas regiões incluem os cromossomos 1p, 2p, 6p, 15p e 18p. Alguns genes, têm sido associados à dislexia tais como: KIAA0319 e DCDC2 no cromossomo $6 p$ e EKN1 no cromossomo 15q.
\end{abstract}

De acordo com Capellini et al (2007), quando os polimorfismos genéticos são identificados, é estimado o desenvolvimento de certos problemas de leitura e escrita, e, se identificados precocemente, pode-se minimizar estes problemas. O desempenho cognitivo também é diferenciado, pois os disléxicos possuem QIV (Quociente Intelectual Verbal) inferior, explicando que há uma velocidade menor para processar a informação e memorizar, o que explica a dificuldade de matemática que os disléxicos geralmente têm, pois envolve aspectos linguísticos, cognitivos, compreensão dos problemas e enunciados. Os cálculos matemáticos exigem correspondência léxico-mental e representação numérica, comprometendo o desempenho para efetuar cálculos.

Capovilla (2004 apud CAPOVILLA et al, 2003), afirma que as habilidades como aritmética, memória fonológica, vocabulário, consciência fonológica e 
sequenciamento, para alfabetizar uma criança, são afetadas nos disléxicos. Ocorre uma dificuldade no processamento fonológico. Conforme Teles (2004, p. 715), o processamento fonológico seria:

A discriminação e processamento dos sons da linguagem, a consciência de que a linguagem é formada por palavras, as palavras por sílabas, as sílabas por fonemas e o conhecimento de que os caracteres do alfabeto são a representação gráfica desses fonemas.

Assim, Teles (2004), explica que a inteligência geral, as noções de linguagem oral e verbal, o vocabulário, a sintaxe, o discurso, o raciocínio e a formação de conceitos acabam sendo prejudicados, pois a leitura ativa três áreas do cérebro no hemisfério esquerdo: a área da região frontal responsável pela da fala, a vocalização e a análise dos fonemas; a região parietal- temporal, onde são analisadas as palavras, visualização das letras, o fonema- letra, a sílaba, na região occipital, onde é processado o conhecimento visual das palavras e feita a leitura rápida e automática, processamento das informações do sistema sensorial, o significado, som e ortografia de cada palavra. E quanto mais automaticamente for feita esta ativação, mais eficiente será a leitura.

Teles (2004) relata que é comum a existência de comorbidades com outras perturbações numa criança disléxica: DDA (Déficit de Atenção), discalculia, hiperatividade, perturbação do comportamento, problemas de coordenação motora etc. Alguns sinais de alerta na infância podem ser suspeita de uma futura dislexia, como: atraso na linguagem oral, quando o bebê não forma frases aos dezoito meses e dois anos de idade, dificuldades de pronunciar as palavras, tendo uma "linguagem de bebê" persistente, dificuldades em aprender os nomes das cores, de pessoas, de objetos, de lugares etc. Dificuldades para memorizar canções, dificuldades de noção espacial, temporal básicos, com identificação das letras de seu nome, dificuldades de reconhecer letras e os seus sons, em crianças até seis anos, são sinais de dislexia.

Conforme Gonçalves; Navarro (2012), aconselham procurar especialistas como psicólogos, médicos, pedagogos, fonoaudiólogos, psicopedagogos, pois são 
profissionais capacitados para iniciar uma minuciosa investigação para o diagnóstico, e quanto mais cedo, melhor será o desenvolvimento da aprendizagem da criança, da autoestima.

\subsection{DIFICULDADE DE ATENÇÃO E MEMÓRIA -TRANSTORNO DE DÉFICIT DE ATENÇÃO/HIPERATIVIDADE - (TDAH)}

De acordo com as entrevistas, os professores relataram que a segunda maior dificuldade de aprendizagem, para $53,3 \%$, é a falta de atenção e memória dos alunos do $1^{\circ}$ ano a $4^{\mathrm{a}}$ série.

Para os educadores é um desafio quando seus alunos não conseguem se manter atentos ao que é ensinado, pois sem atenção e memória a aprendizagem não acontece com sucesso. A mente precisa captar e ser capaz de guardar as informações repassadas pelos professores e assim, aprender cada vez mais e mais. Quando uma criança não consegue prestar atenção, se dispersa muito fácil com qualquer outro fato, barulhos que estão ocorrendo por perto. Se isso acontece com frequência a ponto de prejudicar a aprendizagem, a criança pode estar com um transtorno de Déficit de Atenção conhecido como TDAH de acordo com Golstein et al (2006). Esse transtorno pode estar ou não acompanhado de hiperatividade. Por isso, é importante o diagnóstico de um médico para encaminhar um tratamento e para saber o que a criança realmente tem.

Conforme Rohde e Halpen (2004), as causas ainda são desconhecidas, porém sabe-se que há influências genéticas e ambientais, como saúde emocional geral da criança, desentendimentos familiares e presença de transtornos mentais dos pais.

Segundo Rohde e Halpen (2004), complicações na gestação ou no parto, duração do parto, estresse fetal, baixo peso ao nascer, hemorragia pré-parto, má saúde materna podem causar o transtorno de déficit de atenção. Danos cerebrais perinatais no lobo frontal do cérebro, podem causar desatenção, motivação e afetar o planejamento, relacionando-se indiretamente com o TDAH. 
Conforme (ROHDE; HALPERN, 2004, p 564), comenta que a influência genética é muito forte e:

Que a desatenção, a hiperatividade ou a impulsividade como sintomas isolados podem surgir de muitos problemas na vida das crianças (com pais, colegas e amigos), de sistemas educacionais inadequados, ou podem estar associados a outros comumente encontrados na infância e adolescência.

O transtorno de déficit de atenção com ou sem hiperatividade (TDAH), pode se apresentar diferentes formas: com predomínio de desatenção, com predomínio de hiperatividade e impulsividade ou então desatenção com hiperatividade combinados. O diagnóstico é clínico e se baseia nos seguintes sintomas, conforme Araújo (2002).

Conforme Araújo (2002) em casos de Desatenção a criança que presta pouca atenção, comete erros por falta de atenção, tem dificuldades de se concentrar, parece estar prestando atenção em outras coisas numa conversa, tem dificuldades de seguir instruções e deixa as suas atividades incompletas. Além disso, a criança apresenta dificuldades de se organizar ou planejar com antecedência, não gosta de fazer atividades longas que exigem muito esforço mental, perde seus objetos, esquece compromissos, distrai-se com muita facilidade com coisas à sua volta, ou até com seus pensamentos, esquece as coisas do dia a dia. Em casos de Hiperatividade, a criança apresenta sintomas como mover os pés e as mãos intensamente quando está sentada, possui dificuldades de permanecer sentada na sala de aula, numa mesa de jantar, corre ou trepa em objetos frequentemente em situações inapropriadas, tendo dificuldades em se manter em silêncio em atividades de lazer, é inquieta, impulsiva, é falante que responde às perguntas antes delas ser concluídas, não consegue aguardar a sua vez, interrompe atividades e conversas dos outros.

Rodhe e Halpen (2004) relatam que a criança TDAH, pode ter algum atraso na linguagem, distúrbios na aprendizagem, pois tem limitação no fluxo da fala espontânea, desorganização na elaboração de formas gramaticais, dificuldades de memória e compreensão auditiva, e dificuldades de socialização. O tratamento do TDAH inicia pela orientação da família, e da escola, uma terapia especializada no 
uso de medicamentos. Os pais precisam estabelecer normas de comportamento bem claras e definidas, evitar castigar excessivamente a criança. Posteriormente, é feito com medicamentos como o metilfenidato, com antidepressivos ou clonidina. Quando os casos forem com predominância de desatenção, são fornecidos tratamentos com estimulantes, com o objetivo de melhorar a atenção, e reduzir a hiperatividade quando predomina a impulsividade.

Rohde e Halpern (2004, p 67), relatam que:

Os sintomas de TDAH, ao longo do desenvolvimento, podem causar repetência, expulsões e suspensões escolares, relações difíceis com familiares e colegas, desenvolvimento de ansiedade, depressão, baixa autoestima, problemas de conduta e delinquência, experimentação e abuso de drogas precoces, acidentes de carro, e multas por excesso de velocidade, assim como dificuldade de relacionamento e na vida adulta, no casamento e trabalho.

$\mathrm{Na}$ escola, Rohde e Halpen (2004), sugerem que os professores sejam orientados para que a sala de aula seja bem estruturada, que tenha poucos alunos, rotinas bem-organizadas, consistentes e ambientes escolares previsíveis para que a criança consiga controlar a sua emoção. Estratégias de ensino ativo, com atividades físicas relacionadas ao processo de aprendizagem, são muito importantes. As atividades devem ser curtas, breves, com explicações claras, objetivas, passo a passo, com atendimento individualizado, colocando a criança sempre perto da professora no início da fila da sala, longe de janelas, para não se distrair.

Conforme Kolyniak (2010), é importante o desenvolvimento de atividades psicomotoras com alunos com dificuldades de aprendizagem. Kolyniak (2010, apud Fonseca 2005), afirma que as habilidades motoras fazem exercitar os fatores psicomotores elencados com as estruturas funcionais do cérebro que são atenção, concentração, memorização, formação de conceitos, raciocínio, antecipação e planejamento, imaginação etc. Auxiliando assim, na formação das sinapses dentro do cérebro, sendo utilizadas por outras funções como planejamento, imaginação, associação de informações e memória. 
De acordo com Araújo (2002), o tratamento adequado com medicamentos com acompanhamento multidisciplinar, melhora o desempenho de crianças com falta de atenção na escola. Outros aspectos, podem ser a causa de dificuldade de atenção como problemas oftalmológicos, audiológicos, e o desenvolvimento psicomotor nos primeiros anos de vida podem influenciar na integridade cognitiva de um indivíduo. Um acompanhamento nutricional durante a gravidez e os dois primeiros anos de vida são importantes para um bom desenvolvimento psicomotor. É na puericultura (cuidados primários de saúde de um bebê), que o pediatra, deverá estar bastante atento, pois os fatores de risco estão ligados aos déficits de aprendizagem. A nutrição, as doenças nos primeiros anos de vida, a dinâmica da família são questões importantes, para evitar fatores de risco de baixo rendimento escolar.

\subsection{DIFICULDADE EM MATEMÁTICA}

Conforme a pesquisa realizada, cerca de cinco pessoas, correspondente a $30 \%$ dos entrevistados responderam que a dificuldade em Matemática é uma das maiores dificuldades de aprendizagem na escola. A dificuldade de Matemática, denominada de discalculia a dificuldade em realizar cálculos, dificuldade de noção lógico matemático para realização de atividades, bem como na sua interpretação ao efetuar os cálculos, conforme Silva (2008).

Santos et al (2011), define a discalculia como uma desordem neurológica específica que afeta a capacidade de manipular os números. Segundo Silva (2008), a discalculia é uma inabilidade que envolve a linguística, percepção e atenção, causando falhas ao representar fatos numéricos, nos procedimentos aritméticos, e representação viso- espacial, dificultando realizar cálculos mentais, relacionar conceitos, e saber utilizá-los para a resolução de problemas. As consequências são diversas, como falta de atenção, inconsistência, problemas de linguagem, de organização espacial e orientação temporal, memória, habilidades grafo motoras, habilidades sociais e autoestima. Um desempenho aritmético abaixo do esperado, conforme a sua idade, é um sinal de discalculia. 
Santos et al (2011), afirma que pode ser um impedimento congênito ou hereditário, com um contexto neurológico, causando atrasos cognitivos, problemas linguísticos, dificuldades de atenção e memória etc. Essas dificuldades podem ser resultado de um ensino inadequado, ou insuficiente, sem uma sequência lógica correta, ou desajustado conforme ao nível de desenvolvimento, ao nível de abstração da criança. A discalculia pode ainda causar dificuldades de noção espacial, identificar direita, esquerda, falta de senso de direção (norte, sul, leste, oeste), dificuldades com tabelas do tempo, aritmética mental, dificuldades com noção de tempo com relógios, (horas, minutos, passagem do tempo). Além de tudo isso, tem ainda a inabilidade de planejar o financeiro, o orçamento em seu cotidiano, estimar medidas, distâncias de um lugar ao outro e dificuldade de manter uma contagem durante um jogo.

Segundo Passos et al (2011) existem vários tipos de discalculia:

- Discalculia verbal: é a dificuldade para nomear quantidades, números, termos, símbolos e relações.

- Discalculia practognóstica: é a dificuldade de enumerar, comparar e manipular objetos matematicamente (classificar, ordenar, seriar, agrupar etc.).

- Discalculia léxica: é a dificuldade de ler os símbolos matemáticos.

- Discalculia gráfica: dificuldade de escrever os símbolos matemáticos.

- Discalculia ideognóstica: é a dificuldade em fazer os cálculos mentais, e compreender os conceitos matemáticos, (noção-lógica).

- Discalculia operacional: é a dificuldade de calcular, de usar fórmulas, de montar os cálculos.

De acordo com Almeida (2006, p. 09):

Isso se deve também ao fato de que os primeiros anos de escolarização não foram bem trabalhados e que não haja a contextualização dos conteúdos para que o aluno consiga adquirir habilidades para o raciocínio lógico e resolução de problemas do cotidiano.

Passos et al (2011, apud SILVA 2008), afirma ainda que a criança necessita do material concreto para compreender a matemática, as atividades lúdicas, que 
envolvem a contagem, os números, estratégias e cálculos, trazem uma aprendizagem mais significativa para a criança. E para isso, é muito importante o uso dos jogos de mesa, que são atrativos, criativos na elaboração de estratégias na solução dos problemas, simulam situações, exigindo soluções rápidas.

Assim, o lúdico precisa ser trabalhado de forma significativa, proporcionando o envolvimento, a participação com prazer, ação mental reflexiva, imaginação, fantasia, representação, magia e criatividade. Para que a criança tenha sucesso na Matemática os conceitos matemáticos de espaço, tempo, figuras geométricas, quantidades, tamanhos, diferenças, semelhanças, espaços, localização de objetos, ordenação, calendário, aritmética devem ser bem trabalhados antes de ser alfabetizada. Jogos de mesa, como por exemplo, jogo da memória, resta um, quebra - cabeças, arquiteto, cilada, tangram, material dourado, dominó e brincadeiras organizadas que envolvem contagem, cálculos, ordenação, classificação, seriação, separação por tamanhos, cores, formas, diferenças, semelhanças, noção de espaço lateralidade, são ótimas estratégias para ajudar a superar a discalculia, conforme Passos et al (2011).

Porém, Silva (2008), aponta para a importância do preparo dos professores e profissionais da educação, para que sejam capazes de identificar a discalculia precocemente, encaminhar as crianças se houver necessidade, evitando traumas e consequências maiores. É importante o professor ter conhecimento sobre o assunto para que possa ajudar as crianças, para que tenham um bom desempenho escolar.

\section{CONSIDERAÇÕES FINAIS}

A referida pesquisa originou-se das indagações sobre as dificuldades de aprendizagem encontradas pelos professores das escolas municipais das Séries Iniciais de Pinhalzinho - SC, durante sua prática pedagógica, no decorrer do ano letivo de 2011. Foram relatadas várias dificuldades de aprendizagem, entre elas, dislexia, déficit de atenção e discalculia. Perante estas dificuldades de aprendizagem os professores encontram diversos desafios como: a falta de informação sobre o assunto, falta de apoio escolar para estas situações, falta de material pedagógico, 
distanciamento da família com a escola, falta de profissionais da área para fazer os encaminhamentos necessários, conforme relatado pelos próprios educadores das instituições averiguadas.

Foram apontadas Dificuldades de Leitura e Escrita (Dislexia) em $73 \%$ dos casos, Falta de Atenção (Déficit de Atenção- DDA) 53,3\% e Dificuldades em Matemática (Discalculia) 30\% conforme a Técnica de Interpretação de Bardim (2010) e Trivinos (2009).

Segundo Freitas e Corso (2016) para que as dificuldades de aprendizagem sejam superadas, é preciso que o professor seja um eterno pesquisador, que saiba buscar conhecimentos novos a todo instante, se atualizar e se informar sobre os assuntos referentes as dificuldades de aprendizagem. Buscar uma nova proposta de aprendizagem, onde a criança é protagonista, utilizando-se dos aspectos lúdicos como caminho mais adequado para a prevenção. Valorizar desenvolvimento psicomotor da criança, o desenvolvimento das habilidades motoras, que desenvolvem as demais inteligências e habilidades cognitivas como: noção lógicamatemática, noções fonológicas, atenção, memória, leitura e escrita etc. Esta prevenção pode ser iniciada desde cedo, através do brincar, de brincadeiras diversas, cantigas e jogos que desenvolvam habilidades psicomotoras, psíquicas, cognitivas e afetivas.

É importante ter apoio de uma Equipe Multidisciplinar ou Multiprofissional da Secretaria de Educação (psicopedagogo, psicólogo, terapeuta ocupacional) que faça $o$ atendimento das crianças que apresentam dificuldades no processo de ensino e aprendizagem e auxiliam nos encaminhamentos necessários para profissionais especializados, desde a primeira infância.

No momento, há uma preocupação com as dificuldades de aprendizagem nas escolas municipais, com o desenvolvimento da criança desde a primeira infância, apostando nas aulas de Psicomotricidade para Educação Infantil na faixa etária de zero a três anos, com o desenvolvimento de uma nova metodologia através da ludicidade, uma forma de prevenir as dificuldades de aprendizagem futuras. A 
aritmética, a noção lógico -matemática, a fonologia, atenção e memória podem ser trabalhadas já na Educação Infantil, conforme a idade, com cantigas e histórias infantis que mostram sequências, localização de objetos (em cima, embaixo, ao lado, dentro etc.), quantidades, ordenação. Jogos de mesa como dominó, jogo de memória que envolvem números, quantidades, cálculos pequenos, raciocínio lógico, letras, sílabas, palavras, figuras, quebra cabeças, "tangram", brincadeiras dirigidas, dinâmicas de grupo que contemplam aritmética, atenção, memória, linguagem oral, noções fonológicas são essenciais para prevenir dificuldades de aprendizagem.

Segundo Teixeira (2016), o brincar deverá fazer parte do processo de ensino e aprendizagem, pois é um momento de diversão, capaz de promover a aquisição de aprendizagens e maturações infantis. Através do brincar a criança alcança níveis de aprendizagens imprescindíveis para seu desenvolvimento. Quando as crianças são inseridas na escola, a brincadeira é um meio de interação social e auxílio na aprendizagem, devido seu carácter lúdico e de construção de estruturas mentais superiores que ajudam no desenvolvimento cognitivo da criança.

Focando num trabalho pedagógico lúdico, apoio e orientação da Equipe Multidisciplinar ou Multiprofissional na escola, é possível a prevenção e o tratamento das dificuldades de aprendizagem, de forma adequada, melhorando a qualidade de ensino em todas as etapas.

Enfim, enfatizando a ludicidade, repensando a prática pedagógica, ensinando através do brincar é possível prevenir as dificuldades relacionadas às habilidades de linguagem oral, escrita, noção lógica- matemática, habilidades motoras, prevenindo assim a discalculia e dislexia, minimizando a falta de atenção, melhorando a concentração, raciocínio e memória das crianças, para um melhor desempenho escolar.

É necessário preparar o professor para uma educação baseada na ludicidade, com práticas inovadoras, desafiadoras, um professor pesquisador, que desenvolva todas as habilidades necessárias para a vida da criança. O professor é um profissional que faz toda a diferença na formação humana. A criança somente aprende o que lhe é 
oportunizado. Quanto maior for a qualidade de ensino, quanto mais aspectos lúdicos forem ensinados, melhor a criança irá se desenvolver e menos dificuldades de aprendizagem terá. E consequentemente menos problemas sociais existirão, consequentes das dificuldades de aprendizagem como: exclusão social, desemprego, baixa escolaridade, evasão escolar, pobreza etc.

\section{REFERÊNCIAS}

ALMEIDA, Cinthia Soares de. Dificuldades de Aprendizagem em Matemática e a Percepção dos Professores em Relação a Fatores Associados ao Insucesso nesta Área. 2006. Disponível em: < http://www. poseconomia. ucb.br/sites/100/103/TCC/12006/CinthiasoaresdeAlmeida. pdf. > Acesso em: agosto de 2012.

ARAÚJO, Alexandra P. de Q. C. Avaliação e Manejo da Criança com Dificuldade Escolar e Distúrbio de Atenção. 2002. Disponível em: http://www. scielo. br/pdf/jped/v78s1/v78s1/v78n7a13. pdf Acesso em: nov de 2012.

BARDIN, Laurence. Análise de Conteúdo. 4aㅡ Edição. Edições 70. Lisboa- Portugal. 2010. p. 281.

BRASIL. Base Nacional Comum Curricular (BNCC). Educação é a Base. Brasília, MEC/CONSED/UNDIME, 2017.

CAPELLINI, Simone A. et al. 2007. Desempenho em Consciência Fonológica, Memória Operacional, Leitura e Escrita na Dislexia Familial. Disponível em: <http://www. scielo. br/pdf/pfono/v19n4/a09v19n4. pdf> Acesso em: out de 2012.

CAPOVILLA, Alessandra G. S. GUTSCHOW, Claudia R. D. CAPOVILLA, Fernando C. Habilidades Cognitivas que Predizem Competência de Leitura e Escrita. 2004.

Disponível

em:

>http://pepsic.bvsalud.org/scielo.php?script=sci_arttext\&pid=S1516-

$36872004000200002>$ Acesso em: set de 2012. 
Centro de Estudos Prospectivos de Educação e Cultura. Abolida a Retenção nos Primeiros Três Anos do Ensino Fundamental dos 9 Anos.2014. Disponível em: http://blog.centro destudos.com.br/abolida-a-retencao-nos-primeiros-tres-anos-doensino-fundamental-de-9-anos/ Acesso em: ago de2021.

FREITAS, Clariane do Nascimento. CORSO, Helena Vellinho. A Psicopedagogia na Educação Infantil: O Papel das Brincadeiras na Prevenção das Dificuldades de Aprendizagem. 2016. Revista Psicopedagógica. V.33 no 101.São Paulo.2016. Disponível em: < http://pepsic.bvsalud.org/scielo.php?script=sci_arttext\&pid=S0103$84862016000200010>$ Acesso em agosto de 2021.

GOLSTEIN, Sam. GOLSTEIN, Michael. Hiperatividade Como Desenvolver a Capacidade de Atenção da Criança. 11를 Edição. São Paulo: Papirus, 2006.

GONSALVES, Divina L. S.; NAVARRO, Elaine C. Como Trabalhar com Criança Disléxica. 2012. Disponível em: http://www. revista. univar. edu. br Acesso em: set de 2012.

Lei Complementar N 131de 18/12/2009. Dispõe sobre o Plano de Carreira e Remuneração dos Servidores Públicos Municipais e dá Outras Providências. Disponível em: https://leismunicipais.com.br/plano-de-cargos-e-carreiras-pinhalzinhosc Acesso em set 2021.

Lei Parecer CNE-CEB N11/2010. Diretrizes Nacionais para o Ensino Fundamental de Nove Anos. Disponível em: http://portal.mec.gov.br/index.php?option=com_docman\&view=download\&alias=6324 -pceb011-10\&category_slug=agosto-2010-pdf\&ltemid=30192. Acesso em set 2021.

PASSOS, Adriana Quimentão, et al. Dificuldade de Aprendizagem em Matemática: Discalculia. 2011. Disponível em: <http:/WWW. sumarios. org/sites/default/files/pdf/dificuldade_de_aprendizagem_em matematica_discalculia. pdf. > Acesso em: out de 2012. 
PERRENOUD, Fhilippe. Os Ciclos de Aprendizagem: Um Caminho para Combater o Fracasso Escolar. 1ª Edição. Porto Alegre: Artmed, 2004.

PROJETO POLÍTICO PEDAGÓGICO. Escola Municipal de Educação Básica Theobaldo Utzig, 2019, Pinhalzinho-SC.

PROJETO POLÍTICO PEDAGÓGICO. Escola de Ensino Fundamental Maria Terezinha, 2019, Pinhalzinho-SC.

Projeto de Lei Complementar número 0005/2021. ESTABELECE DIRETRIZES PARA A EDUCAÇÃO ESPECIAL NO MUNICÍPIO DE PINHALZINHO E ALTERA A LEI COMPLEMENTAR N. 130/2009 E DÁ OUTRAS PROVIDÊNCIAS". Disponível em: https://www. camarapzo. sc. gov. br/tramitacoes/1/7575. Acesso em 29 de jun de 2021.

ROHDE, Luis Augusto et al. Transtorno de Déficit de Atenção / Hiperatividade. 2000. Disponível em: < http://www.scielo. br/scielo.php?pid=S151644462000000600003 \& script=sci_arttext> Acesso em: nov de 2012.

ROHDE, Luis Augusto et al. Transtorno de Déficit de Atenção / Hiperatividade na Infância e na Adolescência: Considerações Clínicas e Terapêuticas. 2004. Disponível em: <http://www. scielo.br/pdf/rpc/v31n3/ao2v31n3.pdf> Acesso em: nov de 2012.

ROHDE, A. Luis; HALPERN, Ricardo. Transtorno de Déficit de Atenção/ Hiperatividade: Atualização. 2004. Disponível em: <http://www. scielo. br/pdf/\%0D/jped/v80n2s0/v80n2sa08.pdf> Acesso em: nov de 2012.

SALLES, Jerusa F. de. A, Maria A. M. P. Variabilidade no Desempenho em Tarefas Neuropsicológicas entre Crianças de 2a $2^{\text {a }}$ Serie com Dificuldades de Leitura e Escrita. 2008. Disponível em: <http://seer.psicologia ufrj.br/index.php/abp/article/view/126/143> Acesso em: set de 2012. 
SALLES, Jerusa F. de; PARENTE, Maria A. de M. P. MACHADO, Simone da S. As Dislexias do Desenvolvimento: Aspectos Neuropsicológicos e Cognitivos. 2004. Disponível em: <http://pepsic. bvsalud.org/scielo.php?pid=s141329072004000100007 \& script=sci_arttext> Acesso em: set de 2012.

SILVA, Ana Beatriz B. Mentes Inquietas: Entendendo Melhor o Mundo das Pessoas Distraídas, Impulsivas e Hiperativas.1 1ª Edição. São Paulo: Gente, 2003.

SILVA, Marcelo Carlos da. Dificuldade de Aprendizagem em Matemática: A Manifestação da Discalculia. 2008. Disponível em: <https://proflina.pbworks. com/f/A0427.pdf. > Acesso em: out de 2012.

SILVA, Fabiana Cabral da; SARTORI, Jerônimo. Dificuldades de Aprendizagem: Os Desafios da Carreira Docente. 2012. Disponível em: https://periodicos.ufsm.br/remoa/article/view/6185/3685 . Acesso em: set de 2021.

SILVA, Rejane A.; SOUZA, Luiz A. de P. Aspectos Linguísticos e Sociais Relacionados ao Transtorno de Déficit de Atenção / Hiperatividade. 2005. Disponível em: <http://www. redalyc. org/src/início/ArtPdfRed. jsp/iCve=169320510003> Acesso em: nov de 2012.

TELES, Paula. Dislexia: Como Identificar? Como Intervir? 2004. Disponível em: < https: // www.rpmgf.pt/ojs/index.php/rpmgf/article/view/10097/9834 >. Acesso em: set de 2021.

TRIVINOS, Augusto N. S. Introdução à Pesquisa em Ciências Sociais.1 $1^{a}$ Edição. São Paulo: Atlas S.A. 2009. p. 175.

Enviado: Julho, 2021.

Aprovado: Setembro, 2021 